\title{
O CONTRATO DE LOCAÇÃO FINANCEIRA NO DIREITO PORTUGUÊS: ELEMENTOS ESSENCIAIS*
}

\author{
Raquel Tavares dos Reis*
}

\begin{abstract}
A complexidade da locação financeira dificulta a elaboração de uma noção que cubra todos os aspectos de uma operação contratual que consubstancia uma fonte de obtenção de fundos vantajosa sobretudo para os empresários que pretendem utilizar bens de equipamento, pois que permite ir amortizando os bens com os rendimentos que se vão retirando da sua exploração.

Representando uma operação de financiamento destinada a oferecer um meio de dispor de um determinado bem, locando-o em vez de o comprar, bem se compreende que o locador financeiro não assuma nenhum dos riscos inerentes ao bem locado, designadamente de perda e de deterioração, de responsabilidade por vícios e defeitos e de não realização de prestações a cargo do fornecedor.

Estamos cientes que muito ficará por dizer sobre o contrato de locação financeira, não passando este artigo de uma recolha dos elementos essenciais de uma operação socialmente reconhecível que, construída por união de ingredientes próprios de várias técnicas
\end{abstract}

\footnotetext{
* Assistente estagiária no Instituto Universitário de Desenvolvimento Promoção Social da Universidade Católica Portuguesa - Pólo de Viseu e no Pólo da Figueira da Foz desta mesma Universidade; mestranda em ciências Jurídico-Empresariais na Faculdade de Direito da Universidade de Coimbra.
} 
contratuais, possui características próprias ou especificas que lhe conferem autonomia.

Palavras-chave: origem, noção e âmbito do contrato de locação financeira; regime legal do contrato de locação financeira; natureza jurídica do contrato de locação financeira; jurisprudência portuguesa sobre o contrato de locação financeira.

\section{CAPÍTULO I - ORIGEM, NOÇÃO E ÂMBITO DO CONTRATO DE LOCAÇÃO FINANCEIRA}

\section{A ORIGEM DA PALAVRA E DO CONTRATO}

Quando alguém necessita de um certo bem possui, essencialmente, três alternativas: comprá-lo com os seus próprios recursos, pagando imediatamente o preço correspondente; contrair um empréstimo que permita adquiri-lo; ou celebrar um contrato de locação financeira. Partindo desta ideia, podemos definir a locação financeira como o contrato pelo qual um sujeito, necessitando de um certo bem, em vez de o comprar ou de contrair um empréstimo que permita adquiri-lo, convenciona com um intermediário financeiro que este o adquira (ou faça construir) por sua indicação, com o compromisso de depois lhe ceder o respectivo uso, por um certo prazo e contra o pagamento de uma renda, podendo o primeiro optar pela compra do bem, no fim do contrato.

Normalmente, a operação que esta figura contratual encerra pressupõe a intervenção de três sujeitos: o fornecedor do bem (vendedor ou empreiteiro); o que o pretende utilizar; e aquele que financia a utilização. Mas é a relação contratual que se estabelece entre o financiador e o utilizador que recebe a denominação de locação financeira. Num primeiro passo, o financiador adquire o bem a financiar ou fá-lo construir por sua conta, seguindo as especificações indicadas pelo futuro utilizador. Num segundo momento, o financiador, mantendo a propriedade do bem, coloca-o à disposição do utilizador, que assume todos os riscos e encargos relativos ao mesmo por um determinado período de tempo, durante o qual efectua pagamentos ao financiador. No fim desse período, o utilizador dispõe de uma opção de compra do bem por um determinado preço.

No Decreto-Lei n. ${ }^{\circ}$ 135/79, de 18 de Maio, que introduziu na nossa ordem jurídica a locação financeira, o legislador português exprimiu 
claramente que tomava esta locução como sinónima da palavra inglesa leasing (cfr. o preâmbulo e o artigo $1^{\circ}, \mathrm{n}^{\circ} 1$ do diploma), mas o vocábulo inglês em causa liga-se a um instituto com uma compreensão semelhante à do arrendamento no direito português, o qual não se identifica com a figura que nos ocupa no presente artigo.

Dir-se-á que a expressão, no sentido em que o legislador português a quis utilizar, foi importada, directa ou indirectamente, não da Inglaterra mas dos Estados Unidos da América (EUA). Mesmo assim, questiona-se a sinonímia apontada, porquanto na literatura e na prática norte-americanas se adjectiva vulgarmente a expressão, com vista a restringi-la, falando-se de leasing financeiro e não de leasing tout court, sendo que, nos autores europeus, é igualmente vulgar a adjectivação individualizadora da figura como uma das formas que o leasing pode assumir.

Os autores são praticamente unânimes em apontar os EUA como pátria do contrato de locação financeira, tendo-se aí estruturado como contrato autónomo a partir do início da segunda metade do século passado, passando, a partir da década de sessenta, a ser objecto de utilização sistemática em todos os países europeus economicamente desenvolvidos. Naquele país, o contrato de leasing foi o culminar de uma longa evolução a partir da locação tradicional, sobretudo pela sua aplicação a finns empresariais: em primeiro lugar, pôs-se em evidência que, no plano da empresa, o mais importante não é a propriedade mas o uso de determinados bens no quadro do processo produtivo; depois, começou a encarar-se como opção de gestão financeira o diferimento do pagamento dos investimentos em bens de equipamento, pagando-os com os rendimentos que dos próprios bens se fossem extraindo.

Poderá dizer-se, com Rui Pinto Duarte (2001: 164), que os negócios designados por leasing tiveram essencialmente duas fontes: uma, o interesse em encurtar os prazos de substituição dos bens de equipamento por parte de um número substancial de empresários; outra, o desejo do concedente de crédito de se garantir contra a hipótese de incumprimento por meio do direito de propriedade. Da primeira origem apareceu o leasing dito operacional, esquema negocial que possibilitava aos empresários evitar a compra de bens integrados em sectores sujeitos a rápida evolução tecnológica e permitia substituí-los logo que as necessidades de crescimento da empresa ou a obsolescência dos mesmos tornasse isso recomendável. Da segunda nasceu o leasing financeiro, adjectivação que servia para frisar que o negócio era para o locador uma pura operação de financiamento e que na base do seu surgimento estava 
uma decisão financeira por parte do locatário, alternativa à compra, ainda que a prestações ou com financiamento tradicional ${ }^{1}$.

\section{O CONTRATO DE LOCAÇÃO FINANCEIRA NO DIREITO PORTUGUÊS}

A história da locação financeira em Portugal é, em termos gerais, uma história de sucesso, dela fazendo parte o quadro jurídico da actividade que começou a ser traçado pelo legislador em 1979. Foi, com efeito, em 1979, que foram publicadas as primeiras leis portuguesas sobre a locação financeira: o Decreto-Lei n. ${ }^{\circ} 135 / 79$, de 18 de Maio, sobre as sociedades de locação financeira, e o Decreto-Lei n. ${ }^{\circ}$ 171/79, de 6 de Junho, sobre o contrato de locação financeira, os quais foram entretanto revogados e substituídos pelo Decreto-Lei n. ${ }^{\circ}$ 72/95, de 15 de Abril, o primeiro, e pelo Decreto-Lei n. ${ }^{\circ}$ 149/95, de 24 de Junho, o segundo.

O contrato de locação financeira é, portanto, actualmente, objecto de uma específica regulamentação, aplicando-se-lhe o regime previsto no Decreto-Lei n. ${ }^{\circ}$ 149/95, de 24 de Junho, tendo alguns dos artigos deste diploma sofrido alterações com a entrada em vigor do Decretos-Lei n. ${ }^{\circ} 265 / 97$, de 2 de Outubro e, mais recentemente, do Decreto-Lei n. ${ }^{\circ}$ 285/2001, de 3 de Novembro ${ }^{2}$.

Refira-se ainda, por revestir especial importância, o Regime Geral das Instituições de Crédito e Sociedades Financeiras (RGICSF), aprovado pelo Decreto-Lei n. ${ }^{\circ}$ 298/92, de 31 de Dezembro (e alterado pelos Decretos-Leis n. ${ }^{\circ}$ s 246/95, de 14 de Setembro, 232/96, de 5 de Dezembro, 222/99, de 22 de Junho, pelo Decreto-Lei n. ${ }^{\circ}$ 250/2000, de 13 de Outubro e, mais recentemente, pelo já referido Decreto-Lei n. ${ }^{\circ}$ 285/2001), para o qual remete o artigo $2^{\circ}$ do Decreto-Lei n. $^{\circ} 72 / 95$.

Enquanto negócio jurídico bilateral, aplicar-se-ão à locação financeira, em todos os aspectos que não se encontrem especialmente regulados no Decreto-Lei n. ${ }^{\circ}$ 149/95, também as normas do Código Civil sobre os contratos em geral (artigos $405^{\circ}$ e segs.) e, por analogia, as normas que regulam o contrato de locação simples (artigos $1022^{\circ}$ e segs.). ${ }^{3}$ Em qualquer dos casos, dever-se-á recusar a aplicação das normas que se revelarem incompatíveis com a específica feição da locação financeira (cfr. o artigo $9^{\circ}$, n. $^{\circ} 2,1^{\text {a }}$ parte do Decreto-Lei. ${ }^{\circ}$ 149/95).

$\mathrm{O}$ contrato de locação financeira pode ainda integrar-se no âmbito de aplicação do regime jurídico das cláusulas contratuais gerais (RJCCG), aprovado pelo Decreto-Lei n. ${ }^{\circ}$ 446/85, de 25 de Outubro (e alterado pelos 
Decretos-Leis n. ${ }^{\circ}$ s 220/95, de 31 de Agosto e 249/99, de 7 de Julho). Na verdade, com frequência, os locadores financeiros elaboram prévia e unilateralmente cláusulas contratuais gerais que se destinam a ser incluídas em todos os futuros contratos de locação financeira que vierem a celebrar, com vista a que, em cada caso concreto, apenas se negocie o tipo de bem locado, as rendas a pagar e o prazo do contrato.

Para que haja um contrato de locação financeira previsto e regulado pelo Decreto-Lei n. ${ }^{\circ}$ 149/95, nos termos de cujo n. ${ }^{\circ} 1$ "locação financeira é o contrato pelo qual uma das partes se obriga, mediante retribuição, a ceder à outra o gozo temporário de uma coisa, móvel ou imóvel, adquirida ou construída por indicação desta, e que o locatário financeiro poderá comprar, decorrido o período acordado, por um preço nele determinado ou determinável mediante simples aplicação dos critérios nele fixados", é necessário que se reunam cumulativamente os seguintes pressupostos:

- O locador financeiro tem que ser um banco ou uma sociedade de locação financeira (SLF) constituída nos termos do Decreto-Lei n. ${ }^{\circ} 72 / 95$, entidades que estão sujeitas ao rigoroso e imperativo RGICSF (artigo $4^{\circ}$ do Decreto-Lei n. ${ }^{\circ} 72 / 95$ e artigo $4^{\circ}$, n. ${ }^{\circ} 1$, alínea b) do RGICSF), que passa pela concessão de autorização pelo Banco de Portugal, tendo em conta a particular natureza da actividade financeira que tais entidades desenvolvem.

- O locador financeiro assume a obrigação de adquirir ou mandar construir o bem indicado pelo locatário financeiro (cfr. o artigo $9^{\circ}$, n. ${ }^{\circ} 1$, alínea a) do Decreto-Lei 149/95).

- Por força desta obrigação, o locador financeiro vai celebrar um negócio aquisitivo, sendo a compra e venda e a empreitada os mais frequentes, normalmente com um terceiro ${ }^{4}$.

- O locador financeiro assume a obrigação de conceder o gozo do bem ao outro contraente (cfr. o artigo $9^{\circ}$, n. $^{\circ} 1$, alínea b) do Decreto-Lei 149/95).

- O locatário financeiro obriga-se a pagar uma renda (cfr. o artigo $10^{\circ}, \mathrm{n} .^{\circ} 1$, alínea a) do Decreto-Lei 149/95).

- A cedência do gozo e o pagamento da renda, e, portanto, o contrato de locação financeira, têm um prazo (cfr. o artigo $6^{\circ}$ do Decreto-Lei 149/95).

- O contrato deve prever a opção de compra pelo locatário financeiro, no final do contrato, por um determinado preço.

- O locador financeiro fica com a propriedade do bem, a qual vai desempenhar uma função de garantia do seu investimento ${ }^{5}$. 


\section{O INTERESSE ECONÓMICO DO CONTRATO DE LOCAÇÃO FINANCEIRA}

Da perspectiva do locador financeiro, a locação financeira tem a vantagem decorrente em geral das formas de garantia do financiamento com aquisição pelo credor da propriedade de um bem ou de uma garantia real.

Pelo prisma do locatário financeiro, a locação financeira destaca-se no sistema financeiro como uma forma de financiamento complementar e alternativa para uma ampla gama de potenciais utilizadores, em especial: para o empresário que possui de recursos próprios insuficientes e se encontra, por isso, impossibilitado de renovar ou adquirir bens de equipamento (situação particularmente gravosa quando se detém um stock de bens de equipamento cujas características os tornam sujeitos a uma rápida obsolescência); para o empresário que haja obtido um crescimento significativo graças a uma boa gestão mas tenha alcançado o limite do seu nível de endividamento; e para o novo empresário que, com boas perspectivas de futuro, tenha, porém, escassos recursos próprios para acorrer aos investimentos iniciais necessários.

Para estas entidades, a repercussão económica que a locação financeira traz consigo é colocar ao seu alcance a modernização tecnológica sem necessidade de recorrer a consideráveis imobilizações de capital nem às tradicionais fontes de financiamento, para além de que permite ir amortizando os bens com os rendimentos que se vão retirando da sua exploração ${ }^{6}$.

No que concerne ao consumidor, na medida em que, como veremos melhor, o mecanismo próprio do contrato de locação financeira pode, desde 1995, ser utilizado fora do contexto empresarial, cremos, com Filipe Cassiano dos Santos (1994: 19), que alguns dos aspectos da locação financeira acabarão por convir mal aos seus interesses, tendo em conta, sobretudo, a eventualidade de o consumidor não conseguir retirar, da utilização do bem, rendimentos que lhe permitam custear as rendas.

Para além disto, em se configurando o contrato de locação financeira como um contrato de adesão, são severas as cláusulas contratuais gerais submetidas pelos locadores financeiros à adesão ou à rejeição em bloco dos candidatos a locatários financeiros, podendo da sua celebração decorrer consequências mais gravosas do que benéficas para o consumidor.

É costume apontar à locação financeira as seguintes vantagens principais relativamente a outras fontes de financiamento: permite 
ultrapassar certas dificuldades de concessão de crédito bancário às pequenas e médias empresas ${ }^{7}$; representa um financiamento integral (até $100 \%$ do preço de aquisição); possibilita o estabelecimento de planos de pagamento adaptados às necessidades do locatário financeiro, mediante desenhos ou esquemas operativos "feitos à medida" (flexibilidade); normalmente apresenta taxas de juro efectivas (TAEG) inferiores às do

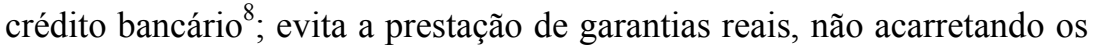
custos a estas relativos.

Entre as principais desvantagens da locação financeira é frequente indicarem-se as seguintes: a locação financeira não fornece o direito de propriedade do bem, durante o período contratual, ao locatário financeiro, limitando a possibilidade de dele dispor antes do final do prazo; as despesas associadas à celebração do contrato de locação financeira são elevadas (comissões, imposto de selo, valor referente ao seguro do bem locado, etc.); na locação financeira de bens imóveis não se aplica o regime de crédito bonificado, daí que, em se visando o uso particular do bem locado, esteja direccionada principalmente para uma classe etária mais jovem, com rendimentos um pouco acima da média; os efeitos fiscais da locação financeira são em tudo idênticos aos efeitos do financiamento bancário, por força do princípio contabilístico da prevalência da substância sobre a forma, de acordo com o qual as operações devem ser contabilizadas atendendo à sua substância e à realidade financeira e não apenas à sua forma legal.

\section{A LOCAÇÃO FINANCEIRA E A LOCAÇÃO SIMPLES}

A regulamentação estabelecida no Decreto-Lei 149/95 encontra-se em grande medida marcada pela referência locatícia do instituto. Ela é patente logo nas designações escolhidas para o contrato (locação financeira), para os sujeitos (locador e locatário) e para a contrapartida a cargo do locatário (renda) e está presente ao longo do regime estabelecido?

É certo que o contrato de locação financeira corresponde a um fenómeno de importação de um mecanismo tradicionalmente usado na esfera civil, a locação, mas com uma profunda alteração da configuração do mesmo, reduzido a instrumento de fins e interesses distintos daqueles que justificam o seu surgimento e hoje conformam o seu regime civil (Cassiano dos Santos, s/d: 1). 
O papel do locador financeiro é apenas o de adquirir o bem e ceder a sua fruição, funcionando a cedência do gozo como um mero instrumento de concretização do financiamento da utilização (e eventual aquisição) de um bem que é escolhido pelo próprio locatário financeiro. Ele não pretende, como o locador tradicional, adquirir o bem para o locar, gozando os rendimentos que tal he poderia proporcionar; mas retirar rendimento do dinheiro investido, naquele ou em qualquer outro bem, sendo o bem irrelevante para o financiador enquanto fonte de rendimento (embora já não, como vimos também, enquanto garantia do reembolso dos valores que investiu no bem $)^{10}$.

É, pois, quando se passa da pura cedência do gozo do bem para a cedência do gozo no quadro de um financiamento, que se ultrapassam os quadros da locação simples para se entrar na locação financeira, bem se compreendendo, se o específico fim do contrato de locação financeira é propiciar um financiamento à utilização (e eventual aquisição) de um bem, que não recaiam sobre o locador financeiro os deveres que normalmente recaem sobre os proprietários que dão em locação.

$\mathrm{O}$ aspecto sublinhado - o específico fim a que se subordina - e a mutação de regime - o locador financeiro não se obriga a assegurar o gozo da coisa para os fins a que ela se destina (cfr. o artigo $1031^{\circ}$, alínea b) do Código Civil com o artigo $9^{\circ}$, n. $^{\circ} 1$, alínea b) do Decreto-Lei n. ${ }^{\circ}$ 149/95), com a eventualidade de o locatário financeiro ter que pagar a renda mesmo sem ter o gozo efectivo e sem a expectativa de o retomar; o locador financeiro não responde pelos vícios da coisa ou pela sua inadequação aos fins do contrato (cfr. o artigo $1032^{\circ}$, alínea b) do Código Civil com o artigo $12^{\circ}$ do Decreto-Lei $n^{\circ}$ 149/95), o que se afigura razoável, pois que o locador financeiro não intervém na escolha nem do fornecedor nem do bem locado; tal como na compra e venda, o risco de perda ou deterioração do bem corre por conta do locatário financeiro, salvo estipulação em contrário (cfr. o artigo $1044^{\circ}$ do Código Civil com o artigo $15^{\circ}$ do Decreto-Lei n. ${ }^{\circ} 149 / 95$ ); o locatário financeiro está obrigado a efectuar o seguro do bem locado, contra o risco da sua perda e deterioração e dos danos por ela provocados (artigo $10^{\circ}, \mathrm{n}^{\circ}{ }^{\circ} 1$, alínea j) do Decreto-Lei n. ${ }^{\circ}$ 149/95); as despesas de transporte e respectivo seguro, montagem, instalação e reparação do bem locado, bem como as despesas necessárias para a sua devolução ao locador financeiro, incluindo as relativas aos seguros, ficam a cargo do locatário financeiro, salvo estipulação em contrário (cfr. o artigo $1030^{\circ}$ do Código Civil com o artigo $14^{\circ}$ do Decreto-Lei n. ${ }^{\circ}$ 149/95); o locador financeiro tem direito a fazer suas, sem compensações, as peças ou outros elementos acessórios 
incorporados no bem pelo locatário (cfr. os artigos $1046^{\circ}$ e $1273^{\circ}$ do Código Civil com o artigo $9^{\circ}$, n. $^{\circ}$ 2, alínea c) do Decreto-Lei n. ${ }^{\circ}$ 149/95); a resolução do contrato de locação financeira não está sujeita ao formalismo a que está a do contrato de locação simples (cfr. os artigos $1047^{\circ}$ e $1048^{\circ}$ do Código Civil com o artigo $17^{\circ}$ do Decreto-Lei n. ${ }^{\circ}$ 149/95) - caracterizam a locação financeira como nova modalidade contratual, designadamente face à locação simples.

\section{A LOCAÇÃO FINANCEIRA E A LOCAÇÃO FINANCEIRA RESTITUTIVA (OU SALE AND LEASE-BACK)}

Costuma caracterizar-se a locação financeira restitutiva (ou sale and lease-back) como a convenção pela qual o proprietário de um bem o vende a outrem, que lho loca de imediato, mediante uma renda e por um certo prazo, para o fim do qual se prevê a possibilidade de o agora locatário voltar a adquirir o bem por um preço residual ${ }^{11}$.

Trata-se, já se vê, de um contrato que representa uma forma de fazer aumentar os meios financeiros do proprietário, pela alienação de um bem do seu património sem prescindir da sua utilização.

Certa posição considera que o sale and lease-back extravasa a noção tipificada de locação financeira, com fundamento, em primeira linha, na diferença entre a função de financiamento da locação financeira e a do sale and lease-back; enquanto o sale and lease-back é uma pura concessão de crédito pela entrada de dinheiro resultante do pagamento do preço de um bem que se vendeu mas se continua a gozar, reembolsando-se esse dinheiro faseadamente, a locação financeira é um financiamento da utilização (e eventual aquisição) de um determinado bem.

Aduz-se, por outro lado, que, fazendo o diploma regulador da locação financeira várias referências ao fornecedor do bem, pressupõe-no sempre como terceiro face ao contrato de locação financeira.

Diz-se ainda que, mesmo que se admitisse o sale and lease-back, ele cairia sempre na previsão do artigo $929^{\circ}, \mathrm{n}^{\circ} 1$ do Código Civil relativa à venda a retro, tanto bastando para dificultar extremamente a viabilidade económica da celebração de tal contrato, já que o prazo aí previsto para o exercício do direito de resolução é demasiado curto ${ }^{12}$.

Do lado oposto, encontram-se os autores que entendem que o sale and lease-back reentra no âmbito da noção tipificada de locação financeira.

Aduz-se, em primeiro lugar, que o argumento de que a sua função é diferente da da locação financeira perde força num sistema de livre acesso 
aos financiamentos, em que não se compreende que não se possa optar pelo sistema de financiamento julgado por decisão do empresário o mais favorável e que não se possa dar livre destino aos capitais injectados.

Defende-se, depois, que o diploma de 1979 foi notoriamente inspirado na experiência jurídica francesa, onde havia já expressa consagração legal do sale and lease-back, pelo que se o legislador português tivesse querido tomar posição sobre o assunto é de presumir que o tivesse feito explicitamente.

Alega-se, por último, que não valem os argumentos exegéticos, pois que os normativos que se referem ao fornecedor como terceiro contêm nas suas próprias letras a previsão da sua aplicabilidade apenas quando a sua hipótese se verifique ${ }^{13}$.

Nós pensamos igualmente que a estrutura tipificada do contrato de locação financeira e o seu regime comportam o sale and lease-back, desde logo porque na definição do artigo $1^{\circ}$ do Decreto-Lei n. ${ }^{\circ}$ 149/95 apenas se exige que a coisa adquirida ou construída o seja por indicação do locatário financeiro, isto implicando que a jusante do contrato de locação financeira haja um outro negócio, mas não forçosamente um outro sujeito, cabendo, assim, na letra da lei a hipótese de o locatário financeiro indicar um bem seu.

Quer dizer, não obstante a operação de locação financeira ser, de um ponto de vista económico, normalmente trilateral - no sentido de que nela intervêm três sujeitos distintos (fornecedor, locador financeiro e locatário financeiro), cujas relações constituem um todo unitário -, de um ponto de vista jurídico o que é determinante é que se vislumbrem dois contratos distintos: a locação financeira e a venda (ou a empreitada), independentemente de a pessoa do locatário financeiro desenvolver ou não uma dupla função de fornecedor e de utilizador do bem.

Para além disto, e decisivamente, o que releva de todo o regime do contrato de locação financeira é que este foi concebido como um mecanismo de financiamento em que deve intervir uma instituição do sector financeiro, sendo que, no plano da sua função económica, o sale and lease-back aproxima-se indiscutivelmente da locação financeira, sendo a liquidez muitas vezes usada, por decisão ulterior ou porque houve uma antecipação do agora locatário financeiro, na compra de um bem que é, assim, indirectamente financiada. 


\section{CAPÍTULO II - REGIME LEGAL DO CONTRATO DE LOCAÇÃO FINANCEIRA}

\section{AS MODALIDADES DO CONTRATO}

Restringido o contrato de locação financeira àqueles contratos em que se descortina um sujeito específico a desempenhar o papel de financiador e em que a concessão do gozo é instrumental desse fim e não o fim do contrato em si mesmo, cabe fazer uma breve referência à frequente classificação do contrato de locação financeira em duas modalidades: mobiliária, quando tenha por objecto bens móveis; e imobiliária, quando tenha por objecto bens imóveis.

$\mathrm{Na}$ nossa lei, tal divisão - cujo relevo prático diminuiu substancialmente após a revogação do Decreto-Lei n. $^{\circ}$ 171/79, que restringia a locação financeira de coisas móveis aos bens de equipamento (artigo $2^{\circ}$ ) e a locação financeira de coisas imóveis aos bens afectados ou a afectar ao investimento produtivo (artigo $3^{\circ}$ ), e do Decreto-Lei n. ${ }^{\circ} 135 / 79$, em cujo artigo $1^{\circ}$, n. $^{\circ} 3$ se determinava que uma mesma SLF só se podia constituir para a prática de uma ou de outra ( $\mathrm{cfr}$. o artigo $3^{\circ}$ do mesmo Decreto-Lei) - projecta-se sobretudo na forma do contrato (cfr. o artigo $3^{\circ}$ do Decreto-Lei n. ${ }^{\circ}$ 149/95), disposições havendo que só se aplicam, pela sua própria natureza, a uma ou a outra de tais modalidades (assim, por exemplo, o artigo $2^{\circ}$, n. $^{\circ} 2$ do Decreto-Lei n. ${ }^{\circ} 149 / 95$ ).

\section{A FORMA E A PUBLICIDADE DO CONTRATO}

Na vigência do Decreto-Lei n. ${ }^{\circ} 171 / 79$, a locação financeira de coisas imóveis tinha de ser celebrada por escritura pública e a de coisas móveis por escrito particular. Nesta última hipótese, seguir-se-ia ou a autenticação notarial ou o reconhecimento por semelhança das assinaturas dos outorgantes, consoante o bem objecto do contrato fosse ou não sujeito a registo (cfr. o artigo $8^{\circ}$ do referido Decreto-Lei). O Decreto-Lei n. ${ }^{\circ}$ 171/79 impunha ainda o registo do contrato sempre que versasse sobre bens registáveis e também a aposição de letreiro indicando a pertença do bem à SLF, quando este fosse móvel (artigo $9^{\circ}$ do Decreto-Lei n. ${ }^{\circ}$ 171/79).

Com a entrada em vigor do Decreto-Lei n. ${ }^{\circ}$ 149/95, o legislador revelou uma clara preocupação de uniformizar e de simplificar, ficando a locação financeira de coisas móveis exclusivamente sujeita à exigência de 
documento particular e bastando para os bens imóveis um documento particular com o reconhecimento presencial das assinaturas das partes, já não sendo necessária a celebração do contrato por escritura pública. No que concerne à publicidade, foi eliminada a exigência da aposição de letreiro nos bens móveis, mantendo-se, todavia, o ónus de registar as locações financeiras de bens imóveis e móveis sujeitos a registo (cfr. o artigo $3^{\circ}$ do Decreto-Lei n. ${ }^{\circ}$ 149/95).

Hoje, depois das alterações introduzidas pelo Decreto-Lei n. ${ }^{\circ}$ 265/97 no artigo $3^{\circ}$ do Decreto-Lei n. $^{\circ}$ 149/95, pode dizer-se que a locação financeira continua a seguir uma tramitação processual muito simples no que toca ao formalismo negocial. Nos termos do actualmente vigente artigo $3^{\circ}$ do Decreto-Lei n. ${ }^{\circ}$ 149/95, a formalidade exigida depende novamente do tipo de bem: os contratos relativos a bens móveis podem, do mesmo modo, ser celebrados por documento particular; para os que tenham por objecto bens imóveis, é necessário um documento particular com reconhecimento presencial das assinaturas das partes, acompanhadas da "indicação, feita pelo respectivo signatário, do número, data e entidade emitente do bilhete de identidade ou documento equivalente emitido pela autoridade competente de um dos países da União Europeia ou do passaporte", e a certificação, pelo notário, da existência de licença de utilização ou de construção. A lei impõe, por último, como já fazia antes, que a locação financeira de imóveis e de móveis sujeitos a registo seja inscrita no registo ${ }^{14}$.

\section{OS SUJEITOS E OS BENS OBJECTO DO CONTRATO}

Não obstante a operação locação financeira ser, normalmente e em termos económicos, uma operação tripartida, os sujeitos do contrato de locação financeira são apenas dois: o locador financeiro e o locatário financeiro, no sentido de que o fornecedor, qualquer que seja a construção que se faça das relações do locador financeiro e do locatário financeiro com ele, é estranho ao contrato de locação financeira.

Vimos já que o locador financeiro deve ser um banco ou uma SLF, constituído(a) nos termos do Decreto-Lei n. ${ }^{0}$ 72/95 e sujeito(a) ao RGICSF (artigo $4^{\circ}$ do Decreto-Lei n. ${ }^{\circ} 72 / 95$ e artigo $4^{\circ}$, n. ${ }^{\circ}$, alínea b) do RGICSF); mas antes da aprovação do RGICSF a categoria de locador financeiro estava reservada às SLF (cfr. o artigo $6^{\circ}, \mathrm{n} .^{\circ} 1$ do revogado Decreto-Lei n. ${ }^{\circ}$ 171/79), exclusividade que se encontrava relacionada com o enquadramento, feito pelo Decreto-Lei n. ${ }^{\circ}$ 135/79 e mantido pelo 
Decreto-Lei n. ${ }^{\circ}$ 103/86, das SLF entre as instituições parabancárias ${ }^{15}$, compreendendo-se que, em conexão com a qualificação das SLF como instituições de crédito (cfr. artigo $3^{\circ}$, alínea g) do RGICSF) ${ }^{16}$, o legislador tenha conferido autorização expressa aos bancos para realizarem operações de locação financeira.

Quanto à assunção da qualidade de locatário financeiro, ela estava, na vigência do Decreto-Lei n. ${ }^{\circ}$ 171/79, restringida aos sujeitos em cuja actividade houvesse lugar à utilização de bens móveis que merecessem a qualificação de bens de equipamento ou de bens imóveis que pudessem ser afectados ao investimento produtivo, em consequência das limitações que a lei impunha, nos artigos $2^{\circ}$ e $3^{\circ}$, ao objecto do contrato de locação financeira ${ }^{17}$.

Com a entrada em vigor do Decreto-Lei n. ${ }^{\circ}$ 149/95, o legislador alargou o campo de utilização do contrato a todos os bens susceptíveis de serem dados em locação (cfr. o artigo $2^{\circ}$, n. $^{\circ} 1$ do referido Decreto-Lei), quer se trate de bens móveis quer de bens imóveis, pelo que se torna admissível o recurso à locação financeira como instrumento financiador do consumo, em virtude de a estrutura jurídica formal em que se resolve a locação financeira ser apta a ter por objecto bens não destinados a fins empresariais, desde que de utilização duradoura.

Tendo a atribuição da qualidade de locatário financeiro deixado de estar sujeita a qualquer tipo de restrição, qualquer pessoa (uma pessoa colectiva, um empresário em nome individual, um profissional liberal ou um consumidor individual) pode ser locatária num contrato de locação financeira.

Em face da evolução legislativa descrita, podem colocar-se vários problemas, em particular: de descaracterização do contrato em virtude de uma eventual subversão do regime essencial do contrato de locação financeira (cfr. o artigo $15^{\circ}$ do Decreto-Lei n. ${ }^{\circ} 149 / 95$, o qual permite que, por estipulação contratual, o risco de perda ou deterioração do bem seja assumido pelo locador financeiro ${ }^{18}$ ); de necessidade de protecção da posição contratual do consumidor, designadamente no que concerne à decisão de $\operatorname{contratar}^{19}$; e de possibilidade de reacção por parte das sociedades financeiras que já actuam na área do crédito ao consumo, designadamente as Sociedades Financeiras para Aquisição a Crédito (SFAC's), previstas e reguladas pelo Decreto-Lei n. ${ }^{\circ}$ 206/95, de 14 de Agosto e pelo RGICSF ${ }^{20}$.

Não obstante tal evolução, o contrato de locação financeira é, na linha da história do instituto, da prática generalizada e do disposto nos ordenamentos que tipificaram a locação financeira, um contrato 
empresarial, no sentido de que consubstancia um meio de financiamento de empresários ${ }^{21} \mathrm{e}$, correlativamente, de que apenas pode ter por objecto bens afectados ou a afectar ao investimento produtivo $^{22}$, não restando dúvidas que o respectivo regime legal se justifica sobretudo quando a relação é entre um financiador-locador e um empresário financiado.

\section{AS RELAÇÕES ENTRE O LOCATÁRIO FINANCEIRO E O FORNECEDOR}

Se é certo que o fornecedor do bem não é, normalmente, parte no contrato de locação financeira, não é menos certo que ele não pode ser ignorado, na medida em que o bem que ele vende ou constrói é simultaneamente objecto do contrato que celebra com o locador financeiro e do que este realizou com o locatário financeiro, ao que acresce que não é o locador financeiro que vai utilizar esse bem (que muitas vezes não chegará sequer a deter materialmente), mas o locatário financeiro.

Habitualmente, o contrato de locação financeira desencadear-se-á por um contacto estabelecido entre o futuro locatário financeiro e o fornecedor, em que aquele escolhe o bem que poderá vir a ser objecto do contrato de locação financeira e negoceia preliminarmente as condições da sua aquisição por um locador financeiro; nesta hipótese, o legislador entende que o interessado age por sua conta e risco, não podendo o locador financeiro ser responsabilizado, pelo fornecedor ou pelo próprio interessado, por prejuízos eventuais decorrentes da não conclusão do contrato (cfr. o artigo $22^{\circ}$ do Decreto-Lei n. $\left.{ }^{\circ} 149 / 95\right)^{23}$.

Depois de ter chegado a acordo nessa negociação preliminar com o fornecedor, o futuro utilizador dirige-se à SLF ou ao banco, apresentando uma proposta contratual em que deve indicar o fornecedor, o bem e as suas características, os prazos de entrega e demais cláusulas do contrato de locação financeira.

Aceite a proposta, a SLF ou o banco e o futuro utilizador celebram o contrato de locação financeira, precisando nas respectivas cláusulas as obrigações de um e de outro.

Formalizado o contrato, proceder-se-á normalmente à aquisição do bem, sendo que é o locador financeiro que contrata com o fornecedor, ainda que muitas vezes, não o faça pessoalmente mas antes se faça representar pelo próprio locatário financeiro ${ }^{24}$. 
Perante este quadro - é o locatário financeiro que, na maior parte das vezes, negoceia e adquire o bem locado, ainda que em nome do banco ou da SLF, estabelecendo uma relação directa com o fornecedor, também depois da compra, caso venha a fazer uso da respectiva opção -, o nosso legislador contemplou, no artigo $13^{\circ}$ do Decreto-Lei n. ${ }^{\circ} 149 / 95$, as relações entre o locatário financeiro e o fornecedor, atribuindo àquele o direito de "exercer, contra o vendedor ou o empreiteiro, quando disso seja caso, todos os direitos relativos ao bem locado ou resultantes do contrato de compra e venda ou de empreitada", possibilidade que, na falta desta norma, competiria ao locador financeiro/proprietário ${ }^{25}$.

\section{OS DIREITOS E AS OBRIGAÇÕES DOS SUJEITOS DO CONTRATO}

As obrigações do locador financeiro restringem-se a adquirir ou a mandar construir o bem a locar; a conceder o gozo do bem (e já não a assegurar, dado o regime de transferência do risco a que faremos referência mais à frente no presente artigo) para os fins a que se destina, abstendo-se de qualquer acto perturbador; e a vender o bem ao locatário financeiro, caso este exerça a opção de compra findo o contrato (artigo $9^{\circ}$, n. ${ }^{\circ} 1$, alíneas a), b) e c) do Decreto-Lei n. ${ }^{\circ}$ 149/95), daí que a posição do locador financeiro se aproxime, quer no plano económico, quer no plano jurídico, da posição do credor detentor da propriedade a título de garantia.

No que concerne aos direitos do locador financeiro, cumpre referir o de defender a integridade do bem, nos termos gerais de direito; o de examinar o bem, sem prejuízo da actividade normal do locatário financeiro; e o de fazer suas, sem compensações, as peças ou outros elementos acessórios incorporados no bem pelo locatário financeiro (artigo $9^{\circ}$, n. $^{\circ}$ 2, alíneas a), b) e c) do Decreto-Lei n. ${ }^{\circ} 149 / 95$ ).

Do artigo $11^{\circ}$, n. $^{\circ} 4$ do Decreto-Lei n. ${ }^{\circ} 149 / 95$ resulta também que o locador financeiro pode transmitir a sua posição contratual sem dependência de autorização do locatário financeiro, regime fundado na mera função de financiador que o locador financeiro desempenha e na consequente sua relativa despersonalização.

Por força do n. $^{\circ} 2$ do artigo $9^{\circ}$ do Decreto-Lei n. ${ }^{\circ} 149 / 95$, a posição jurídica do locador financeiro fica ainda marcada por todos os direitos e deveres gerais previstos no regime da locação simples que não se mostrem incompatíveis com o disposto no Decreto-Lei n. ${ }^{\circ}$ 149/95 (cfr. o artigo $1031^{\circ}$ do Código Civil). 
São, por seu turno, obrigações do locatário financeiro, entre outras, a de pagar as rendas; a de facultar ao locador financeiro o exame do bem locado; a de não aplicar o bem a fim diverso daquele a que ele se destina ou movê-lo para local diferente do contratualmente previsto, salvo autorização do locador financeiro; a de assegurar a conservação do bem e não fazer dele uma utilização imprudente; a de realizar reparações, urgentes ou necessárias, bem como quaisquer obras ordenadas pela autoridade pública; a de não proporcionar a outrem o gozo total ou parcial do bem por meio da cessão onerosa ou gratuita da sua posição jurídica, sublocação ou comodato, excepto se a lei o permitir ou o locador financeiro autorizar; a de comunicar ao locador financeiro, dentro de quinze dias, a cedência do gozo do bem, quando permitida ou autorizada; a de avisar imediatamente o locador financeiro, sempre que tenha conhecimento de vícios no bem ou saiba que o ameaça algum perigo ou que terceiros se arrogam direitos em relação a ele, desde que o facto seja ignorado pelo locador financeiro; a de efectuar o seguro do bem locado, contra o risco da sua perda ou deterioração e dos danos por ela provocados; e a de restituir o bem locado, findo o contrato, em bom estado, salvo as deteriorações inerentes a uma utilização normal, quando não opte pela sua aquisição (artigo $10^{\circ}, \mathrm{n}^{\circ}{ }^{\circ}$, alíneas a), c) e d), e), f), g), h), i), j) e k) do Decreto-Lei n. $\left.{ }^{\circ} 149 / 95\right)^{26}$.

Quanto aos direitos que assistem ao locatário financeiro, destacam-se o de usar e fruir o bem locado; de defender a integridade do bem e o seu gozo, nos termos do seu direito; de usar das acções possessórias, mesmo contra o locador financeiro; de onerar, total ou parcialmente, o seu direito mediante autorização expressa do locador financeiro; de exercer, na locação de fracção autónoma, os direitos próprios do locador, com excepção dos que, pela sua natureza, somente por aquele possam ser exercidos; e o de adquirir o bem locado, findo o contrato, pelo preço estipulado (artigo $10^{\circ}, \mathrm{n}^{\circ}{ }^{2}$, alíneas a), b), c), d), e) e f) do Decreto-Lei n. ${ }^{\circ}$ 149/95).

$\mathrm{O}$ artigo $11^{\circ}, \mathrm{n}^{\circ} 1$ do Decreto-Lei n. $^{\circ}$ 149/95 estabelece ainda que o direito do locatário financeiro pode ser transmitido se o contrato de locação financeira incidir sobre bens de equipamento e houver trespasse de estabelecimento, nos termos do artigo $115^{\circ}$ do Regime do Arrendamento Urbano (RAU), aprovado pelo Decreto-Lei n. ${ }^{\circ} 321-\mathrm{B} / 90$, de 15 de Outubro, ou por morte, a título de sucessão legal ou testamentária, se o sucessor prosseguir a actividade profissional do ex-locatário financeiro. Em qualquer dos casos, o locador financeiro poderá opor-se à transmissão da posição contratual, provando que o cessionário 
não oferece garantias bastantes à execução do contrato (artigo $11^{\circ}$, n. $^{\circ} 3$ do Decreto-Lei 149/95). Quanto aos restantes bens (que não sejam bens de equipamento), o artigo $11^{\circ}$, n. $^{\circ} 2$ remete para o artigo $1059^{\circ}$ do Código Civil, cujo n. 2 remete, por sua vez, para os artigos $424^{\circ}$ e segs. do mesmo Código, dos quais resulta que a transmissão da posição contratual do locatário financeiro carece, nestes casos, de consentimento do locador financeiro (cfr. o artigo $424^{\circ}$, n. $^{\circ} 1$ in fine do Código Civil).

A posição jurídica do locatário financeiro fica, também ela, em virtude do disposto neste artigo $10^{\circ}$, n. $^{\circ} 2$ do Decreto-Lei n. ${ }^{\circ}$ 149/95, marcada por todos os direitos e deveres previstos no regime geral da locação que não se mostrem incompatíveis com o disposto no Decreto-Lei n. ${ }^{\circ}$ 149/95 (cfr. o artigo $1038^{\circ}$ do Código Civil).

\section{O PRAZO DO CONTRATO}

A estipulação do prazo não é absolutamente essencial ao contrato de locação financeira, porquanto, se não for estipulado qualquer prazo, valem supletivamente os prazos previstos no artigo $6^{\circ}, \mathrm{n} .^{\circ} 3$ do Decreto-Lei n. ${ }^{\circ} 149 / 95$, devendo, no entanto, resultar do contrato o seu carácter temporário (Cassiano dos Santos, 1994: 13).

Noutro plano, é de referir que a autonomia negocial em matéria de fixação do prazo do contrato de locação financeira está sujeita a determinados limites, hoje menos estreitos.

$\mathrm{Na}$ vigência do Decreto-Lei n. ${ }^{\circ} 171 / 79$ (cfr. o artigo $11^{\circ}$ ), a locação financeira de coisas móveis ou imóveis não podia ser celebrada por prazos inferiores a dois e dez anos, respectivamente (n. $\left.{ }^{\circ} 1\right)$, e o prazo do contrato, quando este tivesse por objecto bens móveis, deveria corresponder aproximadamente ao período presumível de duração económica da coisa (n. ${ }^{\circ}$ 2). Em qualquer caso, o contrato de locação financeira não poderia ter uma duração superior a trinta anos, havendo uma redução àquele limite sempre que se estipulasse prazo superior (n. $\left.{ }^{\circ} 3\right)$.

Antes das alterações introduzidas pelo Decreto-Lei n. ${ }^{\circ}$ 285/2001, valia o disposto no artigo $6^{\circ}$ do Decreto-Lei 149/95 (anterior redacção), o qual reduzira significativamente o prazo mínimo do contrato, que passou a ser de dezoito meses ou de sete anos consoante estivessem em causa bens móveis ou bens imóveis (n. $\left.{ }^{\circ} 1\right)$. Quanto ao prazo máximo, o regime não sofreu então qualquer alteração, mantendo-se em trinta anos, considerando-se reduzido a este limite quando superior (n. $\left.{ }^{\circ} 2\right)$. Refira-se, 
ainda no âmbito do regime anterior, a alteração pela qual o legislador deixou de exigir que o prazo da locação financeira de coisas móveis fosse determinado em função do período presumível de utilização económica da coisa, exigindo-se (tal como hoje) apenas que o contrato não ultrapasse aquele limite (n. ${ }^{\circ}$ ), podendo, portanto, ficar muito aquém dele.

Actualmente, não se estabelece qualquer prazo mínimo do contrato de locação financeira, dando-se prevalência ao que as partes, no exercício da liberdade de conformação do conteúdo contratual, estabeleçam nas cláusulas "que melhor se acomodem aos objectivos que visam prosseguir" (cfr. o preâmbulo do Decreto-Lei n. ${ }^{\circ}$ 285/2001), o que tem como consequência a possibilidade de se celebrarem contratos de locação financeira por qualquer prazo, mesmo por um dia $^{27}$. Ademais, manteve-se o regime anteriormente vigente, quer quanto ao prazo máximo do contrato, que é de 30 anos, considerando-se reduzido a este limite quando superior ( $\mathrm{n}^{\mathrm{o}} 2$ ), quer quanto à necessidade da locação financeira de coisas móveis não ultrapassar o que corresponde ao período presumível de utilização económica da coisa (n. $\left.{ }^{0} 1\right)$.

\section{AS RENDAS E O VALOR RESIDUAL}

Sabemos que o locatário financeiro se obriga, pelo contrato de locação financeira, a pagar uma retribuição que assume a forma de renda (cfr. o artigo $10^{\circ}$, n. $^{\circ}$, alínea a) do Decreto-Lei 149/95) ou, mais rigorosamente, de contrapartidas financeiras que garantam ao locador financeiro o reembolso do investimento feito, juro calculado sobre o capital investido, custo de amortização dos bens adquiridos e margem de lucro da operação incluídos ${ }^{28}$.

Por ser com o investimento feito pelo locador financeiro que se estabelece, em rigor, a correspectividade, enquanto que na locação simples as rendas são prestações periódicas, correspondentes a períodos sucessivos, dependentes da duração do contrato, na locação financeira há uma obrigação única do locatário financeiro que existe desde a celebração do contrato, embora o seu cumprimento seja fraccionado. Trata-se, assim, de uma obrigação dividida, fraccionada ou repartida quanto ao cumprimento, mas unitária em si mesma, pois que a renda se encontra fixada desde o momento da celebração do contrato em função do preço de aquisição, dos encargos e da margem de lucro.

No âmbito do regime anterior ao Decreto-Lei n. ${ }^{\circ}$ 149/95, a renda deveria permitir, dentro do período de vigência do contrato (que, como 
vimos, para os bens móveis, deveria corresponder à sua presumível vida económica), a amortização total da quantia dispendida pelo locador financeiro e a cobertura dos respectivos encargos e margem de lucro (cfr. o artigo $10^{\circ}, \mathrm{n}^{\mathrm{o}} 1$ do Decreto-Lei 171/79).

Com a entrada em vigor do Decreto-Lei 149/95, a renda apenas teria que possibilitar, dentro do mesmo período [que agora (como então), para os bens móveis, já só não deve ultrapassar o período presumível de utilização económica da coisa], a "recuperação de mais de metade do capital correspondente ao valor do bem locado e cobrir todos os encargos e a margem de lucro do locador" (cfr. o revogado artigo $4^{\circ}$, n. $^{\circ} 1$ do Decreto-Lei 149/95) ${ }^{29}$.

Depois das alterações introduzidas no Decreto-Lei 149/95 pelo Decreto-Lei $n .^{\circ}$ 285/2001, vigora uma ampla liberdade dos sujeitos, na medida em que deixam de existir quaisquer regras sobre o método de cálculo das rendas, para além de que, não se tratando, como veremos ${ }^{30}$, nem de uma locação nem de um mútuo, não se aplicam à locação financeira as regras imperativas que regem a estipulação da remuneração desses negócios, nomeadamente os limites às rendas e as restrições à usura na estipulação da taxa de juro da operação ${ }^{31}$.

No que concerne ao valor residual, este correspondia, no regime anterior, ao montante do capital empregue pelo locador financeiro na aquisição do bem que não viesse a ser amortizado pelas rendas (cfr. o revogado artigo $4^{\circ},{ }^{\circ}{ }^{\circ} 1$, in fine do Decreto-Lei 149/95), ao passo que no regime do Decreto-Lei $\mathrm{n}^{\circ}$ 171/79 era o valor que restava ao bem findo o prazo do contrato (cfr. o artigo $10^{\circ}$, n. $^{\circ} 3$ do Decreto-Lei n. ${ }^{\circ} 171 / 79$ ).

Hoje, trata-se de um valor livremente negociado entre o locador financeiro e o locatário financeiro, não fazendo o regime actual qualquer referência ao limite máximo do montante não amortizado pelas rendas ${ }^{32}$, considerando-se que "a transparência das condições contratuais e a livre concorrência consubstanciam formas adequadas de acautelar a protecção dos consumidores dos serviços prestados pelas instituições habilitadas à realização de actividades de locação financeira" (cfr. novamente o preâmbulo do Decreto--Lei n. ${ }^{\circ}$ 285/2001) ${ }^{33}$.

\section{A OPÇÃO DE COMPRA E O PREÇO DE AQUISIÇÃO}

Pelo contrato de locação financeira, o locador financeiro obriga-se a vender o bem ao locatário financeiro, caso este o queira, findo o contrato (artigo $9^{\circ}$, n. $^{\circ}$ 1, alínea c) do Decreto-Lei 149/95) ou, correlativamente, 
pelo prisma do locatário financeiro, este tem o direito de adquirir o bem locado, findo o contrato, pelo preço estipulado no contrato (artigo $10^{\circ}$, n. $^{\circ} 2$, alínea f) do Decreto-Lei 149/95) ou determinável mediante simples aplicação dos critérios nele fixados (artigo $1^{\circ}$, in fine do Decreto-Lei 149/95); trata-se da chamada opção de compra do locatário financeiro ${ }^{34}$.

Em regra, o locatário financeiro deseja apenas obter a disponibilidade do bem, não querendo adquirir a propriedade do mesmo, pelo que protela o juízo sobre a oportunidade da aquisição para um momento posterior, no qual terá em conta os factores custo e progresso tecnológico. Para além disto, na maior parte dos casos, o investimento do locador financeiro está, no final do contrato, praticamente reembolsado, pelo que não se compreenderia que ficasse também com o bem locado.

A aquisição do bem por parte do locatário financeiro não é automática com o pagamento da última renda ou com o termo do contrato, sendo necessária quer uma declaração do locatário financeiro no sentido da aquisição, quer a celebração de um novo contrato de compra e venda, que se regerá pelas normas gerais aplicáveis a este tipo contratual (Cassiano dos Santos, 1994: 15).

Temos com melhor interpretação das disposições legais relativas à opção de compra (que se referem à venda como conteúdo de uma obrigação) a que considera que o mecanismo da opção de compra se reconduz a um contrato-promessa unilateral de venda (de coisa futura cfr. o artigo $467^{\circ}$, n. $^{\circ} 2$ do Código Comercial), inserto num contrato de locação financeira, que obriga o locador financeiro perante o locatário financeiro ${ }^{35}$.

Quanto ao preço de aquisição a pagar pelo locatário financeiro, este deve, como vimos, estar determinado no contrato ou ser determinável mediante simples aplicação dos critérios nele previstos (cfr., novamente, o artigo $1^{\circ}$, in fine do Decreto-Lei n. $\left.{ }^{\circ} 149 / 95\right)$.

Se faltar o preço ou o critério para o determinar (ou acordo complementar do contrato), o legislador não fornece qualquer indicação nem estabelece qualquer restrição no que toca à determinação do preço final do bem ${ }^{36}$, pelo estamos perante um contrato de compra e venda em que o preço deve ser determinado nos termos do artigo $883^{\circ}$ do Código Civil. Não assim, diga-se, ao abrigo do regime anterior ao Decreto-Lei n. ${ }^{\circ}$ 149/95, em que a determinação do preço de aquisição do bem estava legalmente restringida, devendo corresponder ao presumível valor residual do bem (cfr. o artigo $10^{\circ}$, n. $^{\circ} 3$ do Decreto-Lei n. ${ }^{\circ}$ 171/79). 


\section{O PERÍODO DE VIGÊNCIA DO CONTRATO}

O período de vigência do contrato de locação financeira (cfr. o artigo $8^{\circ}$, n. $^{\circ} 1$ do Decreto-Lei n. $\left.{ }^{\circ} 149 / 95\right)$ é marcado por uma transferência do risco similar à que se operaria se o locatário financeiro adquirisse a propriedade do bem, não obstante por ele haver uma mera cedência do gozo: ao contrário do que se passa na compra e venda e na locação simples, o locador financeiro não responde pelos vícios do bem locado ou pela sua inadequação face aos fins do contrato, salvo o disposto no artigo $1034^{\circ}$ do Código Civil (artigo $12^{\circ}$ do Decreto-Lei n. $\left.{ }^{\circ} 149 / 95\right)^{37}$; tal como na compra e venda, mas ao contrário do que ocorre na locação simples, o risco de perda ou deterioração do bem corre por conta do locatário financeiro, salvo estipulação em contrário (artigo $15^{\circ}$ do Decreto-Lei n. ${ }^{0}$ 149/95); do mesmo modo, é ao locatário financeiro que compete suportar todas as despesas de transporte, montagem, instalação e reparação da coisa locada (artigo $14^{\circ}$ do Decreto-Lei n. ${ }^{\circ}$ 149/95).

Perante este quadro, cabe ao locatário financeiro verificar a conformidade do bem entregue com as especificações e a ausência de defeitos, podendo eventualmente prevalecer-se de cláusula contratual que condicione o início da vigência do contrato à entrega em conformidade $\mathrm{e}$ sem defeitos (cfr. o artigo $8^{\circ}$, n. $^{\circ} 2$, in fine do Decreto-Lei n. $\left.{ }^{\circ} 149 / 95\right)^{38}$.

\section{A CESSAÇÃO DO CONTRATO}

O contrato de locação financeira pode cessar por caducidade, por resolução ou por revogação, mas não por denúncia, porquanto o contrato é celebrado, nos termos já assinalados, por um certo prazo, no termo do qual, o contrato extingue-se por caducidade, não se aplicando as normas dos artigos $1054^{\circ}$ e segs. do Código Civil, quer por serem incompatíveis com a finalidade do contrato de locação financeira (a renovação automática poderia pôr em causa o equilíbrio das prestações), quer por a sua aplicação ser contrariada pelo próprio regime legal, que em várias normas pressupõe a cessação do contrato com o decurso do prazo [cfr. os $\operatorname{artigos} 7^{\circ}$ e $10^{\circ}$, n. ${ }^{\circ} 1$, alínea k) do Decreto-Lei n. $\left.{ }^{\circ} 149 / 95\right]$.

Em caso de caducidade do contrato, três possibilidades ficam em aberto: ou o locatário financeiro exerce o direito de adquirir o bem locado [artigos $9^{\circ}$, n. $^{\circ} 1$, alínea c) e $10^{\circ}, n^{\circ}{ }^{2}$, alínea f) do Decreto-Lei n. $\left.{ }^{\circ} 149 / 95\right]$; ou o locatário financeiro não exerce esse direito, mas acorda com o locador financeiro a renovação do contrato, ao abrigo do disposto 
no artigo $7^{\circ}$ do Decreto-Lei n. ${ }^{\circ} 149 / 95$, podendo o contrato de locação financeira prever $\log$ o direito do locatário financeiro de exigir a renovação ou a renovação automática se nenhum dos sujeitos declarar outra vontade em certo prazo; ou o locatário financeiro não exerce a opção de compra nem há acordo de renovação, ficando obrigado a restituir a coisa locada [artigo $10^{\circ}, \mathrm{n}^{\circ}{ }^{1}$, alínea k) do Decreto-Lei n. $\left.{ }^{\circ} 149 / 95\right]^{39}$.

Vimos que o contrato também pode extinguir-se por resolução, a qual pode ser accionada por qualquer das partes, nos termos gerais, com fundamento em incumprimento (artigo $17^{\circ}$ do Decreto-Lei n. $\left.{ }^{\circ} 149 / 95\right)^{40}$, ou pelo locador financeiro, com fundamento em dissolução ou liquidação da sociedade locatária ou na verificação de qualquer dos fundamentos de declaração de falência do locatário financeiro (artigo $18^{\circ}$ do Decreto-Lei n. ${ }^{\circ}$ 149/95).

Em se dando o incumprimento definitivo pelo locatário financeiro, o locador financeiro pode, pois, resolver o contrato, reavendo o bem locado e exigindo o pagamento das rendas vencidas e não pagas (cfr. o artigo $434^{\circ}$, n. $^{\circ} 1$ do Código Civil) ${ }^{41}$, bem como uma indemnização (cfr. o artigo $801^{\circ}$, n. ${ }^{\circ} 2$ do Código Civil), incluindo o contrato, frequentemente, cláusulas que prevêem pressupostos de resolução, designadamente quanto à falta de pagamento de rendas, muitas vezes acrescidas de cláusulas penais (cfr. os artigos $810^{\circ}$ e segs. do Código Civil).

O contrato pode ainda cessar pela sua anulação ou declaração de nulidade, nos termos gerais, não afectando a invalidade (nem a resolução) da locação financeira o contrato de compra e venda (ou de empreitada) ${ }^{42}$, sendo antes as vicissitudes destes contratos que afectam o destino da locação financeira, pois que, operando quer a invalidade quer a resolução retroactivamente, com o contrato de compra e venda (ou de empreitada) cai o objecto do contrato de locação financeira, tudo se passando como se o locador financeiro não tivesse cumprido as obrigações de adquirir e de conceder o gozo do bem ${ }^{43}$.

\section{CAPÍTULO III - NATUREZA JURÍDICA DO CONTRATO DE LOCAÇÃO FINANCEIRA}

Várias têm sido as posições doutrinárias adoptadas no que concerne à natureza jurídica do contrato de locação financeira, sendo que a primeira questão que se coloca é a de saber se estamos perante um tipo contratual autónomo e distinto da locação ou se se trata ainda de uma espécie do 
género locação, embora especialmente qualificada pelo escopo financeiro que lhe preside, sendo muito discutida na doutrina a fronteira entre a locação financeira e as demais formas de utilização da locação, bem como a própria licitude desta utilização, em virtude de o artigo $23^{\circ}$ do Decreto-Lei n. ${ }^{\circ} 149 / 95$ prever que "nenhuma entidade pode realizar, de forma habitual, operações de natureza similar ou com resultados económicos equivalentes aos do contrato de locação financeira."

Se, no actual mercado de bens duradouros, há casos em que o que as partes querem é mesmo a concessão do gozo temporário do bem, há também muitos outros em que as partes não têm como horizonte primário a devolução do bem ao locador; casos em que o recurso à locação é apenas uma forma de o concedente de crédito se garantir por meio do direito de propriedade, consubstanciando a locação, combinada com uma promessa unilateral de venda (locação com opção de compra), ou até só por si mas integrando uma cláusula segundo a qual a coisa locada "se tornará propriedade do locatário depois de satisfeitas todas as rendas ou alugueres pactuados", para utilizar as palavras do artigo $936^{\circ}$, n. $^{\circ} 2$ do Código Civil (locação-venda), uma alternativa à compra e venda a prestações com reserva de propriedade, para assim se obterem efeitos práticos semelhantes aos propiciados por esta via ${ }^{44}$.

Neste contexto, alguma doutrina, sobretudo italiana, tem reconduzido a locação financeira à compra e venda a prestações com reserva de propriedade ${ }^{45}$; mas um importante sector doutrinal português afasta tal concepção, com fundamento sobretudo na falta de automaticidade do efeito translativo na locação financeira, a qual, diz-se, traduz uma diferença vocacional dos dois institutos: na compra e venda a prestações com reserva de propriedade a finalidade visada consiste na aquisição da propriedade, que só não ocorre de imediato porque o comprador não pode ou não quer dispor de toda a quantia do preço, verificando-se essa transferência, necessariamente, quando a totalidade do preço estiver pago; na locação financeira, o locatário financeiro não quer tornar-se proprietário, mas gozar da faculdade de utilizar o bem, diferindo para um momento posterior a decisão sobre a aquisição da propriedade ${ }^{46}$.

No que respeita à locação em geral, são, como sublinhámos já, vários os aspectos do regime socialmente típico e do regime legalmente previsto da locação financeira que perturbam o enquadramento desta técnica naquele tipo contratual.

Desde logo, o contexto em que o contrato surge e os interesses a que responde são distintos: o locador financeiro adquire para dar o gozo e como forma de financiar a utilização (e eventual aquisição) de um bem 
pelo interessado; o locador tradicional pretende, sem mais, dar o gozo, retirando as vantagens que o bem lhe pode dar.

Depois, repete-se, está ausente na locação financeira a específica relação que intercede na locação entre o gozo e a renda: nesta, a renda é apurada em função da diminuição das utilidades que com ela o proprietário vai suportar e das vantagens que, por seu turno, o locatário dela vai retirar; na locação financeira, a renda não tem qualquer relação directa com as vantagens propiciadas pelo gozo, sendo antes estabelecida em função da amortização do preço do bem pago no início pelo financiador, dos custos e da margem de lucro deste.

Mesmo no plano em que mais se assemelham, o da cedência do gozo de um bem, esta intercede a título distinto do locatício, tratando-se, na locação financeira, de uma cedência do gozo atípica ${ }^{47}$.

Decisivamente no sentido do afastamento da locação financeira em relação à locação, refira-se a faculdade conferida ao locatário financeiro de exercer os direitos decorrentes para o locador financeiro do negócio aquisitivo.

Tudo isto confirma a ideia de que a locação financeira é um contrato autónomo em face da locação, pois que apresenta assinaláveis diferenças em relação ao tipo definido no Código Civil; na medida em que o seu regime resulte da lei, não há que procurar reconduzi-la a este tipo contratual elementar.

Outros autores defendem que a locação financeira deve ser reconduzida à figura do mútuo, porquanto, diz-se, a estrutura trilateral típica da operação económica locação financeira é apenas de carácter formal, tudo se passando como se fosse o locador financeiro a entregar a quantia mutuada directamente ao locatário financeiro.

Argumenta-se, por outro lado, que a transferência da propriedade tem, no mútuo, uma simples função instrumental, de permitir a utilização da coisa, residindo a essência da mesma na possibilidade de o mutuário utilizar a coisa mutuada para satisfação das suas necessidades.

Aduz-se ainda que todo o contexto que envolve a locação financeira tende a valorizar o aspecto pecuniário em detrimento do bem material, designadamente: o locador financeiro ser uma instituição de crédito; ao locador financeiro não interessar o bem de per se mas a soma envolvida; e o ser o utilizador que se dirige ao locador financeiro com vista a obter um financiamento ${ }^{48}$.

Pensamos, com Pedro António Sequeira de Oliveira (1995: 194), que as apontadas semelhanças do escopo financeiro destes dois contratos não podem fazer esquecer que finalidade do contrato não se confunde com 
natureza jurídica do mesmo, ressaltando, a mais disto, que a locação financeira não tem por objecto dinheiro ou outra coisa fungível, nem o locatário financeiro está obrigado a restituir algo do mesmo género e quantidade (cfr. o artigo $1142^{\circ}$ do Código Civil), ao que acresce que a cedência do gozo do bem influi, decisivamente, no regime do contrato do locação financeira.

Digna de referência é a posição que considera o contrato de locação financeira um contrato misto, por as suas prestações se encontrarem compreendidas em espécies típicas directamente reguladas na lei: a locação e a compra e venda ${ }^{49}$.

Num sentido algo divergente, Rui Pinto Duarte (2001: 83) defende que a locação financeira é uma união de contratos, posição que julgamos ser a que melhor apreende a especificidade desta técnica contratual ${ }^{50}$, pois que, pela união de contratos, as partes pretendem instituir um nexo entre dois ou mais contratos para alcançarem um fim ulterior, distinto do fim próprio dos contratos singulares, os quais se mantêm diferenciados, conservando a sua individualidade embora conexos por um vínculo que influi no respectivo regime jurídico ${ }^{51}$.

E, na locação financeira, temos ligados entre si por um vínculo funcional duas espécies contratuais típicas: um contrato de locação e um contrato-promessa unilateral de venda (ao locador financeiro compete ceder o gozo de um determinado bem ao locatário financeiro e a este assiste o direito de optar pela compra do mesmo findo o contrato), sendo que o vínculo funcional que se cria e influi a disciplina de tais contratos não faz perder a sua autonomia no esquema negocial unitário e autónomo de composição de interesses que a locação financeira consubstancia.

Sendo os problemas envolvidos na união de contratos diversos dos relativos à tipicidade e atipicidade contratual, cumpre ainda referir que, a mais de ser construída por união de ingredientes próprios das referidas técnicas contratuais, a locação financeira possui características próprias ou específicas quanto a vários aspectos da relação contratual; características que conferem à locação financeira individualidade e autonomia em relação àquelas técnicas contratuais, ainda que com traços comuns, ressaltando os elementos da cedência atípica do gozo e do financiamento da utilização (e eventual aquisição) de bens, praticado por entidades sujeitas a um regime rigoroso de regras atinentes à particular natureza da actividade creditícia que desenvolvem ${ }^{52}$. 


\section{CAPÍTULO IV - JURISPRUDÊNCIA PORTUGUESA SOBRE O CONTRATO DE LOCAÇÃO FINANCEIRA}

Ao sucesso e desenvolvimento do contrato de locação financeira corresponde um certo grau de litigiosidade, estando a comprová-lo o facto de a locação financeira constar da lista de contratos que integra o modelo de impresso de requerimento de injunção, aprovado pela Portaria $n .^{\circ}$ 902/98, de 15 de Outubro.

Seguindo de perto Rui Pinto Duarte (2001: 212 e 213), dir-se-á que os principais problemas relativos ao regime da locação financeira que se suscitam nos tribunais portugueses são os seguintes:

- Inaplicabilidade à locação financeira do regime especial da compra e venda a prestações constante dos artigos $934^{\circ}$ e segs. do Código Civil - Acórdãos da Relação de Lisboa, de 29 de Junho de 1989, de 25 de Janeiro de 1990, de 19 de Maio de 1992 e de 18 de Fevereiro de 1999, publicados na $C J$, ano XIV, tomo IV, pp. 111 e segs., ano $\mathrm{XV}$, tomo I, pp. 149 e segs., ano XVII, tomo III, pp. 178 e segs. e ano XXIV, tomo I, pp. 113 e segs., respectivamente.

- Validade das cláusulas que conferem ao locador financeiro, em caso de incumprimento pelo locatário financeiro, o direito de, em alternativa à resolução do contrato, exigir o pagamento antecipado das rendas vincendas - Acórdãos da Relação de Lisboa, de 13 de Março de 1990, do STJ, de 7 de Março de 1991, da Relação de Coimbra, de 23 de Novembro de 1993, do STJ, de 5 de Julho de 1994, da Relação de Lisboa, de 20 de Setembro de 1994; Acórdãos do STJ, de 17 de Novembro de 1994, de 18 de Maio de 1995 e de 5 de Novembro de 1997; Acórdão da Relação de Lisboa, de 5 de Março de 1998 e Acórdãos do STJ, de 20 de Janeiro de 1999 e de 10 de Fevereiro de 2000, publicados na $C J$, ano XV, tomo II, pp. 129 e segs., no $B M J$, n. $^{\circ} 405$, pp. 465 e segs., na $C J$, ano XVIII, tomo V, pp. 225 e segs., na $C J-S T J$, ano II, tomo II, pp. 170 e segs., na $C J$, ano XIX, tomo IV, pp. 90 e segs., no $B M J$, n. ${ }^{\circ} 441$, p. 274, na $C J-S T J$, ano III, tomo II, pp. 94 e segs. e ano V, tomo III, pp. 120 e segs., na $C J$, ano XXIII, tomo II, pp. 85 e segs., na $C J-S T J$, ano VI, tomo III, pp. 73 e segs., ano VII, tomo I, pp. e ano VIII, tomo I, pp. 76 e segs., respectivamente.

- Consequências sobre os direitos e obrigações recíprocos do locador financeiro e do locatário financeiro da não entrega do bem locado pelo fornecedor - Acórdãos do STJ de 22 de Novembro de 1994 e de 30 de Novembro de 1995, publicados na CJ-STJ, ano II, tomo 
III, pp. 155 e segs. e ano III, tomo III, pp. 132 e segs.; Acórdão da Relação do Porto, de 12 de Junho de 1997; Acórdão da Relação de Lisboa, de 22 de Janeiro de 1998 e Acórdão da Relação do Porto, de 12 de Outubro de 1999.

- Validade da cláusula penal que, em caso de resolução do contrato com fundamento em incumprimento pelo locatário financeiro, obriga este a pagar uma importância igual a $20 \%$ do valor global que resulta da soma das rendas vincendas com o valor residual e juros - Acórdão da Relação de Coimbra, de 23 de Novembro de 1993, publicado na $C J$, ano XVIII, tomo V, pp. 225 e segs. e Acórdãos da Relação de Lisboa, de 27 de Abril de 1995 e de 2 de Novembro de 1995.

- Necessidade de controle, ao abrigo do regime jurídico das cláusulas contratuais gerais (em se tratando de um contrato de adesão que as preveja) ou do instituto da redução equitativa, da cláusula penal desproporcionada ou manifestamente excessiva ${ }^{53}-$ Acórdão do STJ, de 9 de Março de 1993, publicado na $C J-S T J$, ano I, tomo II, pp. 8 e segs. e na Revista Sub Judice, Set-Dez 1993, pp. 61 e segs.; Acórdão da Relação do Porto, de 23 de Fevereiro de 1995; Acórdão da Relação de Lisboa, de 30 de Setembro de 1997; Acórdão da Relação do Porto, de 2 de Abril de 1998; Acórdão do STJ, de 9 de Fevereiro de 1999 e Acórdão da Relação do Porto, de 19 de Abril de 1999.

Quanto ao primeiro dos problemas referidos, todas as decisões referidas vão no sentido da irrecondutibilidade da locação financeira à locação-venda e, por conseguinte, da inaplicabilidade à locação financeira do regime especial da compra e venda a prestações constante dos artigos $934^{\circ}$ e segs. do Código Civil ${ }^{54}$.

No que concerne ao problema da chamada, na prática negocial anglo-americana, acceleration clause, não restam dúvidas que a generalidade dos locadores financeiros insere nos seus modelos de contrato uma cláusula segundo a qual, em caso de incumprimento pelo locatário financeiro, o locador financeiro pode, em alternativa à resolução do contrato, exigir o valor das rendas vincendas, tendo a validade desta cláusula de vencimento antecipado das rendas sido contestada nalguns (muitos) processos judiciais ${ }^{55}$.

Tal cláusula, quando abrange também o pagamento de uma indemnização por mora no pagamento das rendas vencidas e o valor residual, tem o alcance de, contra a essência da locação financeira, obrigar o locatário financeiro a comprar o bem locado; mas a acceleration 
clause que se cinja às rendas vincendas, prevendo a perda do benefício do prazo pelo locatário financeiro, enquadra-se, segundo pensamos, perfeitamente no espírito do contrato de locação financeira ${ }^{56}$, na medida em que o contrato de locação financeira supõe uma vultuosa mobilização de capitais por parte do locador financeiro, com vista à aquisição dos bens locados, tendo-se também presente o elevado risco que o locador financeiro corre, dado o desgaste que o bem locado sofre e que o pode tornar sem préstimo depois de recuperado ${ }^{57}$.

Refira-se, ainda a favor da admissibilidade da atribuição deste direito ao locador financeiro, o artigo $13^{\circ}$, n. $^{\circ} 2$ da Convenção do Unidroit sobre Locação Financeira Internacional, aprovada em Otava em 28 de Maio de 1988, o qual permite expressamente a cláusula em questão (Duarte, 2001: $186)^{58}$.

É, pois, de afirmar a validade de princípio da cláusula que atribui ao locador financeiro o direito de, em caso de incumprimento pelo locatário financeiro, exigir antecipadamente o montante das rendas vincendas ${ }^{59}$, sendo que, nesta hipótese, o locador financeiro não pode resolver o contrato; tal daria lugar a um seu enriquecimento injusto, na medida em que acabaria por receber mais do que aquilo que obteria se o contrato fosse pontualmente cumprido, já que receberia a prestação do locatário financeiro sem cumprir a sua, porquanto, pela restituição do bem locado, impediria o gozo pelo locatário financeiro ${ }^{60}$.

Põe-se, em terceiro lugar, o problema da validade de cláusulas segundo as quais o incumprimento da obrigação de entrega do bem locado pelo fornecedor não responsabiliza o locador financeiro; antes pelo contrário, obriga o locatário financeiro a proceder ao pagamento das rendas devidas, não podendo resolver o contrato de locação financeira ${ }^{61}$.

Determinado sector doutrinal defende que não impende sobre o locador financeiro a obrigação de entrega material do bem ao locatário financeiro, estando apenas obrigado a celebrar o negócio aquisitivo e a permitir que o bem venha a ser entregue ao locatário financeiro nas condições acordadas entre este e o fornecedor, aduzindo-se que, segundo a intenção das partes, tal obrigação não cabe na esfera contratual do locador financeiro, o qual cumpre o contrato quando celebra o negócio aquisitivo e posteriormente possibilita a cedência do gozo do bem, justamente porque desempenha única e exclusivamente uma função de intermediário financeiro ${ }^{62}$.

Outra posição entende que a assimilação da locação financeira à locação em geral conduz a que se conceba a obrigação de conceder o gozo da coisa como a principal obrigação do locador financeiro, não 
podendo conceder-se o gozo da coisa sem a entrega (instrumental) da mesma ao locatário, daí que a obrigação de entrega da coisa recaia sobre o locador financeiro.

Recaindo a obrigação de entrega da coisa ao locatário sobre o locador financeiro, este tanto pode cumpri-la directamente (se tiver a coisa em seu poder) como valendo-se da cooperação do fornecedor (estipulando com o fornecedor que a entregue directamente ao locatário financeiro e com este que a receba directamente daquele), sendo esta a praxis negocial ${ }^{63}$.

Nestes casos, explicam, o fornecedor é auxiliar do locador financeiro no cumprimento da obrigação de entrega (artigo $800^{\circ}$ do Código Civil) e o locatário financeiro recebe a coisa em nome próprio e em nome da sociedade locadora: em nome próprio, porque esse direito lhe advém do contrato de locação financeira; em nome da sociedade locadora, porque esta, tendo direito à entrega da coisa por força do contrato de compra e venda, lhe conferiu mandato para esse efeito.

Defende-se, em decorrência, que são nulas as cláusulas pelas quais o locador financeiro transfere para o locatário financeiro o risco da não entrega ou do atraso na entrega do bem locado, pois que representam uma grave turbação da equivalência prestacional do contrato ${ }^{64}$.

Por nós, somos do parecer que cláusulas com o conteúdo das referidas devem considerar-se válidas, correndo o risco da falta de entrega ou do atraso na entrega do bem por conta do locatário financeiro, o qual continua, assim, obrigado ao pagamento das rendas ao locador financeiro, a não ser que, como vimos, possa prevalecer-se de cláusula contratual que condicione o início de vigência do contrato à entrega em conformidade $\mathrm{e}$ sem defeitos.

Não nos restam dúvidas que faz parte do contrato de locação financeira a obrigação do locador financeiro de entrega da coisa ao locatário financeiro para que este a possa gozar, respondendo o locador financeiro por actos próprios (cfr. o artigo $798^{\circ}$ do Código Civil) ou do fornecedor como seu auxiliar (cfr., novamente, o artigo $800^{\circ}$ do Código Civil); mas tal não impede que, ao abrigo da liberdade de modelação do conteúdo dos contratos consagrada no artigo $405^{\circ}$ do Código Civil, se preveja o afastamento expresso da obrigação de entrega da coisa, com a inerente transferência para o locatário financeiro do risco da não entrega ou do atraso na entrega, quer esta se deva ao fornecedor quer ao próprio locador financeiro ${ }^{65}$.

Trata-se de uma cláusula destinada a definir o objecto do contrato que é a consagração da isenção de responsabilidade do locador financeiro pela realização de prestações a cargo do fornecedor ${ }^{66}$; consideramo-la válida 
por não nos parecer que a obrigação de entrega material do bem ao locatário financeiro seja uma obrigação essencial para se alcançar o escopo prosseguido pelas partes, neste sentido apontando a própria lei, que parece excluir essa obrigação da esfera jurídica do locador financeiro (cfr. o artigo $9^{\circ}$, n. ${ }^{\circ} 1$ do Decreto-Lei n. ${ }^{\circ} 149 / 95$ com o artigo $1031^{\circ}$ do Código Civil).

Pela análise das cláusulas contratuais constata-se ainda que as partes estipulam frequentes vezes que, em caso de resolução do contrato com fundamento em incumprimento pelo locatário financeiro, este se obriga, para além de a restituir o bem locado e a pagar as rendas vencidas até à resolução, a pagar uma importância, a título de cláusula penal, igual a $20 \%$ do valor global que resulta da soma das rendas ainda não vencidas com o valor residual e juros ${ }^{67}$.

A questão da natureza da indemnização que, nos termos do artigo $801^{\circ}$, n..$^{\circ} 2$ do Código Civil, se cumula com a resolução do contrato continua a ser muito discutida, adoptando a maior parte da doutrina e da jurisprudência a tese de que, se o locador financeiro opta pela resolução do contrato, a indemnização que lhe é devida fica circunscrita ao interesse contratual negativo ou dano da confiança, o qual tem e vista colocar o credor na situação em que se encontraria no caso de não ter celebrado o contrato, abrangendo os danos emergentes (por exemplo, as despesas do contrato) e os lucros cessantes (por exemplo, os juros) ${ }^{68}$.

Tendo em conta que não cabe no âmbito do presente estudo desenvolver esta problemática ${ }^{69}$, o que importa relevar é que certa jurisprudência tem considerado que a cláusula mencionada está ferida de nulidade, entre o mais porque "os preceitos injuntivos dos artigos $433^{\circ} \mathrm{e}$ $434^{\circ}$ do Cód. Civil, ao determinarem a destruição da relação contratual por virtude de resolução pelo credor, não lhe concedem outros direitos senão os da restituição do equipamento e do reembolso das rendas vencidas, com os respectivos juros moratórios. ${ }^{70}$

$\mathrm{Na}$ linha da jurisprudência mais recente, pensamos que é de considerar válida a demanda da resolução do contrato de locação financeira conjuntamente com uma indemnização calculada em função das rendas vincendas e do valor residual ${ }^{71}$; esta visa ressarcir danos que não são de alguma forma cobertos pelos demais efeitos da resolução, pois que, como vimos já, os contratos de locação financeira acarretam elevados riscos para o locador financeiro, inerentes ao elevado investimento feito, ao desgaste e desvalorização dos bens que sejam recuperados por força da extinção antecipada do contrato e à impossibilidade de obter os lucros que o cumprimento do contrato produziria, não podendo asseverar-se que os 
danos sofridos em consequência da resolução são ressarcidos pela restituição do bem locado (Sequeira de Oliveira, 1995: 247 e 248).

Para além disto, a cláusula penal que aqui analisamos exerce uma função de fixação antecipada do montante da indemnização devida no caso de o locador financeiro resolver o contrato com fundamento em incumprimento (cfr. artigo $801^{\circ}$, n. $^{\circ} 2$ do Código Civil), trazendo notórias vantagens quer aos locadores financeiros, por inverter o ónus da prova e evitar a morosidade e a litigiosidade inerentes à prova dos danos, quer aos próprios locatários financeiros, por afastar o risco de uma indemnização superior às expectativas.

Esta cláusula é, portanto, regra geral, válida, embora, em certos casos, o seu exercício possa ser reputado de abusivo por força dos artigos $19^{\circ}$, alínea c) e $12^{\circ}$ do RJCCG e, noutros, a cláusula penal possa ser reduzida, nos termos do artigo $812^{\circ}$ do Código Civil ${ }^{72}$.

Sendo aconselhável que as decisões judiciais revelem a preocupação de evitar o enriquecimento injustificado do locador financeiro, com vista a garantir alguma transparência nas operações de intermediação financeira $^{73}$, pensamos que uma cláusula que preveja uma indemnização de $20 \%$ da soma do valor das rendas vincendas com o valor residual e juros nunca permitirá ao locador financeiro obter mais do que esperava com o cumprimento pontual do contrato de locação financeira.

\section{NOTAS}

* O artigo que ora se publica, com ligeiras adaptações, foi apresentado como relatório da disciplina de Direito Comercial do curso de mestrado em Ciências Jurídico-Empresariais, ministrado pela Faculdade de Direito da Universidade de Coimbra.

${ }^{1}$ Note-se que o financial leasing, tal como é caracterizado pelos autores norte-americanos, é uma figura mais lata do que a nossa locação financeira, já que aqueles não exigem que o locador financeiro seja uma sociedade financeira nem que o locatário financeiro tenha direito a adquirir o bem, findo o prazo do contrato, embora também não excluam esta possibilidade. Certo é que o leasing financeiro se distingue do leasing operacional que lhe está na origem por naquele a motivação principal do locatário ser o financiamento da utilização (e eventual aquisição) de um determinado bem e neste tal motivação ser antes fugir aos riscos próprios da propriedade, tudo com reflexos na estrutura do negócio [Filipe Cassiano dos Santos, «O contrato de leasing», 
Apontamentos de Direito Comercial II, Faculdade de Direito da Universidade de Coimbra, 1994, p. 2, ensina que "normalmente este contrato coenvolve a prestação de serviços por parte do locador (de manutenção, nomeadamente) e o risco de avaria ou perecimento do bem corre por conta do locador"] e na duração do contrato [Richard A. Brealey e Stewart C. Meyers, Principles of Corporate Finance, Mcgraw-Hill, International Editions, $4^{\mathrm{a}}$ ed., 1991, p. 654, escreve: "Some leases are short-term and cancelable during the contract period at the option of the lessee: these are generally known as operating leases. Others extend over most of the estimated economic life of the asset and cannot be canceled or can be cancelled only if the lessor is reimbursed for any losses: these are called capital, financial, or full-payout leases"]. Já se vê que locação operacional é umas vezes associada ao facto de serem prestados pelo locador serviços de manutenção e assistência técnica, outras ao prazo (curto) da locação, outras ainda à relação entre as rendas e o valor dos bens locados e ao ter (ou não) incluída uma opção de compra no final do contrato. Dir-se-á que a locação operacional abrange todas as operações referidas, consumindo-se esta figura contratual numa mera cedência temporária do gozo de um bem, sem que interceda um intermediário financeiro (ainda que, por vezes, se converta numa locação com opção de compra ou mesmo numa locação-venda, por força da inclusão de cláusulas de opção ou de aquisição automática); a sua razão de ser é claramente a recusa de investir, de imobilizar capital num bem sujeito a rápida obsolescência e não já, como na locação financeira, uma decisão relativa ao investimento. Neste contexto, o nosso legislador equipara a locação operacional à locação simples (cfr. o preâmbulo do recentemente publicado Decreto-Lei n. ${ }^{\circ}$ 285/2001, de 3 de Novembro, que alterou o regime da locação financeira), estabelecendo a Directriz Contabilística n. ${ }^{\circ} 25$, Diário da República, II série, de 11 de Maio de 2000, critérios (exaustivos) para a classificação contabilística das locações como operacionais ou financeiras.

2 Ao lado deste diploma de carácter geral, o legislador português previra, em 1991, um tipo especial de contrato de locação financeira de imóveis destinados a habitação, que estava regulado no Decreto-Lei n. ${ }^{\circ}$ 10/91, de 9 de Janeiro, entretanto revogado pelo já referido Decreto-Lei n..$^{\circ}$ 265/97, estando, hoje, este tipo de contratos sujeito ao regime geral constante do Decreto-Lei n. ${ }^{\circ}$ 149/95, com as alterações introduzidas pelo Decreto-Lei n. ${ }^{\circ}$ 265/97 e pelo Decreto-Lei n. ${ }^{\circ}$ 285/2001.

3 Neste sentido, v. Filipe Cassiano dos Santos, «Um exemplo das novas tendências do direito comercial: o contrato de locação financeira entre a origem civilística e a comercialidade», Apontamentos de Direito Comercial II, Faculdade de Direito da Universidade de Coimbra, (sem data - s/d), p. 12.

${ }^{4}$ Sobre a possibilidade de o locatário financeiro indicar ao fornecedor a aquisição de um bem seu, cfr. infra ponto 5. 
${ }^{5}$ Note-se que o valor da propriedade do bem enquanto garantia do investimento é diminuto no caso dos móveis sujeitos a rápida obsolescência ou desvalorização, a ponto de a prática desconfiar desse valor com a exigência pelos locadores financeiros que os locatários financeiros subscrevam livranças ou aceitem letras destinadas a dotarem aqueles de títulos executivos, para o caso de incumprimento. A tal exigência soma-se correntemente a da prestação de aval às obrigações cambiárias em causa (Rui Pinto Duarte, Escritos sobre leasing e factoring, Principia, S. João do Estoril, 2001, p. 208, nota 3 ).

${ }^{6}$ No sentido do texto, cfr. o Acórdão do Supremo Tribunal de Justiça (doravante STJ), de 7 de Março de 1991, Boletim do Ministério da Justiça (doravante BMJ), n. ${ }^{\circ}$ 405-Abril-1991, p. 467: "A moderna empresa tem necessidade frequente de actualizar seus bens de equipamento já que eles, a curto prazo, oferecem sinais de cansaço e não apresentam toda a gama de novas vantagens e a eliminação de defeitos que o novo artigo apresenta. Esta vertiginosa sucessão de coisas cada vez mais sofisticadas e cada vez mais caras coloca o empresário mediano, pouco capitalizado (como sucede à maioria das nossas empresas) perante um dilema: ou ele não moderniza o seu parque de bens de equipamento e é ultrapassado pela concorrência ou imobiliza largos capitais na aquisição - com todos os inconvenientes daí decorrentes. Justamente para obviar a esta dificuldade foi que surgiu a nova figura do contrato de locação financeira, na sua espécie mobiliária, como solução moderna, adequada à solução do problema da actualização do equipamento produtivo sem necessidade de dispender vultuosas quantias em dinheiro para tal fim, com insuportável frequência."

7 Entende-se por pequenas e médias empresas, para os efeitos previstos no Regime de Apoio à Adaptação das Pequenas e Médias Empresas ao Euro, aprovado pelo Decreto-Lei n. ${ }^{\circ}$ 256/99, de 7 de Julho de 1999, as empresas que estejam constituídas como empresa em nome individual, sociedade comercial, agrupamento complementar de empresas ou cooperativa que possuam "menos de 50 trabalhadores e um volume de negócios inferior a 1 milhão de contos" (artigo $3^{\circ}$ do mencionado regime). Note-se, a talhe de foice, que, com a moeda única, o crédito continuará em Portugal a ser mais caro, dada a relativa maior fragilidade e atraso económico do nosso país - os investimentos são sempre mais arriscados (no País e nas nossas empresas) e o risco, na lógica bancária, paga-se caro.

${ }^{8}$ Refiram-se, a este propósito, os resultados do teste prático realizado pela revista Dinheiro \& Direitos, edição de Setembro de 2001, p. 39, acerca da melhor forma de financiar a aquisição de automóvel: "O aluguer de longa duração (ALD) e o leasing, sobretudo se comercializados por bancos e outras entidades financiadoras exteriores aos concessionários, são as formas de financiamento que apresentam as taxas de juro efectivas (TAEG) mais reduzidas. No leasing, por exemplo, foi sempre possível conseguir valores abaixo dos 7,5\%. Esta situação não é de admirar, pois, através do 
ALD e do leasing, a empresa mantém a propriedade do automóvel. Logo, o seu risco é menor. Inversamente, são as sociedades financeiras de aquisição a crédito, conhecidas por SFAC, a cobrar os valores mais elevados (quase $20 \%$, num dos concessionários da Citroën!). No entanto, o ALD e o leasing não são a opção indicada para quem quiser ser o proprietário do automóvel desde o início do contrato. Neste caso, sobram duas alternativas: as SFAC, que, como foi referido, podem ser caras, e o crédito bancário. Assim, quem não se importa de não ser dono do automóvel desde o início tem vantagem em optar pelo leasing, uma vez que pratica as taxas mais reduzidas." Mais recentemente, conclui-se no mesmo sentido: "O leasing continua a ser a forma de financiamento automóvel mais barata. Mas, se se fizer questão em ser proprietário desde o início, o crédito no banco poderá ser a solução adequada" (Dinheiro \& Direitos, edição de Fevereiro/Março de 2002, p. 9). Apesar da proximidade do ALD à locação financeira, estamos perante figuras contratuais distintas, na sua caracterização e na disciplina que envolvem. Em primeiro lugar, o ALD logrou vencer no mercado automóvel, tendo em vista, sobretudo, contornar certas limitações impostas pelas regras imperativas da locação financeira e libertar o mercado das medidas legislativas restritivas do crédito ao consumo, enquanto que a locação financeira nasceu, como vimos, no mercado dos bens (móveis e imóveis) afectados ou a afectar ao investimento produtivo. Outra grande diferença situa-se ao nível da aquisição da propriedade do bem, existindo uma expectativa muito grande de o locatário em ALD vir a exercer a opção de compra, a qual satisfaz o interesse do locatário de adquirir o bem depois de ter pago o respectivo preço. Refira-se ainda que o ALD integra, com crescente frequência, a prestação de serviços adicionais por parte do locador, designadamente sob a forma de seguros, assistência técnica, manutenção e fornecimento de viaturas de substituição, pois que é praticado por empresas não constituídas como sociedades do sector financeiro. Em suma, não obstante os locadores de ALD tentarem, pela via contratual, o que o legislador português concedeu aos locadores financeiros em matéria de risco de perda ou deterioração do bem e de responsabilidade pelos vícios e defeitos do mesmo, o ALD tem, predominantemente, como pano de fundo, o regime da locação simples, apontando-se para um progressivo afastamento relativamente à locação financeira, na medida em que se vão introduzindo no ALD novas modalidades de prestações que reforçam a posição do locador tradicional enquanto se acentuam os traços de financiamento concedido para a utilização (e eventual compra) de bens na locação financeira. No que respeita especificamente a automóveis, existe no nosso ordenamento jurídico legislação sobre a actividade de aluguer de veículos automóveis sem condutor (cfr. os Decretos-Leis n. ${ }^{\circ}$ s 354/86, de 23 de Outubro e 15/88, de 16 de Janeiro), a qual teve, porém, sobretudo em vista o renting, contrato pensado para aqueles casos em que um sujeito precisa circunstancialmente de um certo bem de consumo duradouro para o 
utilizar numa tarefa determinada (o aluguer de automóveis a turistas, por exemplo). Segundo a revista Dinheiro \& Direitos, últ. ed. cit., p. 13, este contrato "é ideal para quem não quer ter nenhuma preocupação com o carro. É óbvio que esta demissão de responsabilidades tem o seu custo, tornando-o uma opção bastante cara e apenas acessível a algumas carteiras." A necessidade do bem é, ao contrário do que se passa no ALD, sempre meramente acidental, o que se reflecte na duração (inferior) do contrato. Trata-se, pois, de um contrato de locação, à semelhança do ALD.

${ }^{9}$ Veja-se a remissão, em matéria de objecto, para a locação simples; as remissões, em matéria de direitos e deveres dos sujeitos, para o regime da locação; e o envio para o disposto em matéria de locação no que concerne à cessão da posição de locatário financeiro de bens que não sejam de equipamento (cfr. os artigos $2^{\circ},{ }^{\circ} .^{\circ} 1,9^{\circ},{ }^{\circ}{ }^{\circ} 2$, $10^{\circ},{ }^{\circ}{ }^{\circ} 2$ e $11^{\circ},{ }^{o}{ }^{2}$ do Decreto-Lei n. $\left.{ }^{\circ} 149 / 95\right)$.

${ }^{10}$ Nas palavras de Filipe Cassiano dos Santos, «O contrato de leasing» cit., p. 8: "Na locação a propriedade é pressuposto do contrato, enquanto que no leasing decorre do próprio contrato, surgindo depois e por causa das obrigações nele assumidas."

${ }^{11}$ Filipe Cassiano dos Santos, «O contrato de leasing»... cit., p. 2, define, em termos muito semelhantes, a locação financeira restitutiva como o contrato pelo qual "um sujeito adquire ou se compromete a adquirir a outro um certo bem, pagando-lhe o preço respectivo, mas comprometendo-se simultaneamente a, após a compra, ceder o gozo do bem ao anterior proprietário mediante uma renda e por um certo prazo, para o fim do qual, normalmente, se prevê um direito de compra do bem por um preço residual."

${ }^{12}$ V. Rui Pinto Duarte, ob. cit., pp. 49 e segs.. Refira-se, contudo, a mudança de posição que assume na p. 180 desta sua obra. Digna de referência é, pela sua originalidade, a posição de Massimo La Torre, «Le tipologie particolari dell'operazione», Manuale del leasing, EGEA, 1998, Milano, pp. 177 e segs., que defende impor-se reconhecer autonomia estrutural e funcional ao sale and lease-back. Segundo o autor, trata-se de uma operação económica complexa que responde a uma exigência específica, característica da actividade empresarial, do vendedor/utilizador de, no quadro de um determinado plano económico de obtenção de factores produtivos de natureza financeira, obter liquidez, através da alienação de um bem do património empresarial com a intenção de readquirir a propriedade do mesmo no fim do contrato. São, assim, características peculiares do contrato de sale and lease-back, tal como o autor o configura: num plano subjectivo, a natureza empresarial do utilizador, que deverá ser titular de uma empresa que carece de injecção de fundos; num plano objectivo, o bem deve ser um bem imóvel ou móvel de equipamento; não devem existir entre o comprador/concedente e o utilizador débitos anteriores.

${ }^{13}$ V. Filipe Cassiano dos Santos, «O contrato de leasing»... cit., pp. 20 e segs., Diogo Leite de Campos, «Nota sobre a admissibilidade da locação financeira 
restitutiva (lease-back) no direito português», Revista da Ordem dos Advogados, ano 42, III, Set-Dez, 1982, pp. 775 e segs. e Duarte Vieira Pestana de Vasconcelos, «A locação financeira», Revista da Ordem dos Advogados, ano 45, I, Abril, 1985, pp. 262 e segs..

${ }^{14}$ Rui Pinto Duarte, ob. cit., p. 183, considera que "a razão de ser do registo da locação financeira, em Portugal, não é a oponibilidade a terceiros do direito do locador sobre a coisa locada. Sendo este direito do locador o direito de propriedade, para que ele seja oponível a terceiros o que é necessário é apenas que seja ele (direito de propriedade) registado - e não a locação financeira. O registo da locação financeira tem, assim, uma escassa relevância."

15 A categoria de instituições parabancárias era definida pelo Decreto-Lei n. ${ }^{\circ}$ 46302, de 27 de Abril de 1975, como abrangendo as instituições que, não sendo instituições de crédito (institutos de crédito do Estado, bancos emissores, bancos comerciais e estabelecimentos especiais de crédito) nem exercendo funções auxiliares de crédito (bolsas, correctores e casas de câmbio), exerciam alguma função de crédito ou qualquer actividade que pudesse afectar de forma especial o funcionamento dos mercados monetário e financeiro.

${ }^{16}$ Instituição de crédito é, segundo a definição comunitária, a empresa cuja actividade consiste em receber do público depósitos ou outros fundos reembolsáveis e conceder crédito por sua própria conta (cfr. o artigo $1^{\circ}$ da Directiva 77/780/CE, de 12 de Dezembro de 1977 - Primeira Directiva de Coordenação Bancária). Note-se que, nos termos do artigo $14^{\circ}$, n..$^{\circ}$, alínea a) do RGICSF, as instituições de crédito com sede em Portugal devem adoptar a forma de sociedade (comercial) anónima.

${ }^{17}$ Com vista a contornar o regime legal proibitivo da locação financeira de bens móveis que não fossem de equipamento e a ultrapassarem, deste modo, o âmbito essencialmente empresarial das suas carteiras de clientes, deu-se o caso de algumas SLF cederem veículos automóveis em regime de locação financeira a empresas intermediárias com conhecimento de que tais veículos iriam posteriormente ser cedidos a terceiros em regime de ALD. Assim, os casos decididos pelos Acórdãos da Relação de Lisboa, de 18 de Fevereiro de 1999, Colectânea de Jurisprudência (doravante $C J$ ), ano XXIV, tomo I, pp. 113 e segs. e de 15 de Março de 2000, CJ, ano $\mathrm{XXV}$, tomo II, pp. 94 e segs., podendo ler-se na p. 97 deste último Acórdão: "As locadoras, perante a proibição legal de se destinarem ao consumo de bens móveis que apenas poderiam ser destinados a equipamento e perante a expectativa de maiores ganhos, fragilizadas ainda no plano da boa fé pelo estratagema desviante e com a sua capacidade de esclarecimento negocial afectada pela mira de lucros habilidosos, ter-se-iam assim deixado enredar pela gelatinosa teia negocial e, por culpa sua, não leram na comunicação do seguro aquilo que noutras circunstâncias não deixariam 
imediatamente de ver: que o seguro-caução não garantia aquilo que as locadoras queriam que garantisse."

${ }^{18}$ Ainda que duvidemos que a faculdade de se prever estipulação em contrário seja usada na prática negocial, por ferir gravosamente os interesses do locador financeiro, sendo que os bancos e as SLF não prevêem nos contratos que celebram qualquer alteração às disposições contratuais (valor das rendas e prazos de pagamento) no caso de destruição total ou parcial do bem, persistindo a obrigação de pagar as rendas acordadas. Neste contexto, a lei impõe, como veremos a seguir no texto, que o locatário financeiro efectue o seguro da coisa contra o risco da sua perda ou deterioração, com o que se salvaguarda o banco ou a SLF contra o risco de insolvência do locatário financeiro.

${ }^{19}$ Neste quadro, saliente-se a posição que sustenta a aplicabilidade ao contrato de locação financeira, sempre que utilizado por consumidores, das normas do Decreto-Lei n. ${ }^{\circ}$ 359/91, de 21 de Setembro (alterado pelo Decreto-Lei n. ${ }^{\circ}$ 101/2000, de 2 de Junho), que regulamenta os contratos de crédito ao consumo, designadamente do prazo de reflexão previsto no artigo $8^{\circ}$ deste diploma (neste sentido, v. Ricardo Munhoz, «Contrato de leasing (locação financeira)», Revista Portuguesa de Direito de Consumo, n. ${ }^{\circ}$ 12, Dez. de 1997, Coimbra, p. 16).

${ }^{20}$ A propósito do alargamento do objecto do contrato aos bens de consumo, Filipe Cassiano dos Santos, «Um exemplo das novas tendências do direito comercial: o contrato de locação financeira entre a origem civilística e a comercialidade», Apontamentos de Direito Comercial II, Faculdade de Direito da Universidade de Coimbra, sem data - s/d, p. 1, levanta o problema de saber se estamos perante um verdadeiro mecanismo comercial ou se se trata antes de um contrato civil, concluindo que o alargamento do objecto do contrato aos bens de consumo não descaracteriza $o$ regime comercial, antes, pelo contrário, conduz a uma extensão desse regime a relações que são exteriores à esfera mercantil, a ponto de se suscitarem dúvidas sobre a conveniência da estrita aplicação do regime pensado para as relações comerciais a essas novas esferas; segundo o autor, tal alargamento demonstra o carácter pioneiro da vida mercantil e do direito comercial, revelado na invenção de instrumentos que são depois postos à disposição das zonas civis.

${ }^{21}$ Cfr. o Acórdão da Relação de Lisboa, de 8 de Junho de 2000 (disponível, assim como os restantes a que faremos referência sem indicação de local de publicação, no site www.dgsi.pt da Internet), cujo sumário em parte se transcreve: "I. O objectivo final do contrato de locação financeira é a concessão de crédito para financiamento do uso do bem e de disponibilização de acrescidos instrumentos tendentes a possibilitar o exercício de uma actividade produtiva." 
${ }^{22}$ Segundo informa Rui Pinto Duarte, ob. cit., p. 181, quer a lei francesa, quer a lei belga, quer ainda a lei espanhola restringem expressamente o objecto do contrato de locação financeira aos bens de equipamento.

${ }^{23}$ Note-se que a parte final deste artigo $22^{\circ}$ ressalva a possível aplicação do artigo $227^{\circ}$ do Código Civil, podendo haver lugar a um pedido de indemnização por responsabilidade pré-contratual, se os pressupostos desta norma se verificarem, designadamente quando tenha havido já contactos entre o fornecedor e o banco ou a SLF e este(a) tenha gerado a aparência de que o contrato de locação financeira iria ser celebrado.

${ }^{24}$ Cfr. o Acórdão do STJ, de 20 de Outubro de 1998, cujo sumário em parte se transcreve: "III. A relação jurídica entre o locador e o locatário representa, no que respeita à aquisição do material, um contrato, ainda que tácito, de mandato para a sua compra." No sentido de que o mandato não é um elemento próprio do contrato de locação financeira mas algo que lhe é justaposto, v. Rui Pinto Duarte, ob. cit., p. 56.

${ }^{25}$ A atribuição ao locatário financeiro do direito de demandar judicialmente o fornecedor para o exercício de direitos que caberiam ao locador financeiro tem conduzido grande parte da doutrina a tentar levantar uma construção que dê forma jurídica ao carácter trilateral da operação económica em que normalmente se consubstancia a locação financeira. Para mais desenvolvimentos, v. últ. aut. e ob. cit., pp. 54 e segs..

${ }^{26}$ Note-se que quase todos os deveres referidos no texto correspondem ao interesse do locador financeiro decorrente da função de garantia da propriedade e da possibilidade de retomar o bem, no fim do contrato.

${ }^{27} \mathrm{Na}$ prática negocial, o prazo do contrato tenderá, contudo, a coincidir com o período de vida económica do bem, para que se permita a amortização do preço por ele pago durante a vigência do contrato.

${ }^{28}$ Vários eram os aspectos de regime que confirmavam que, na locação financeira, a renda não representa uma contrapartida do gozo do bem, como na locação simples, sendo antes basicamente estabelecida em função do investimento feito pelo financiador: os critérios legalmente estabelecidos para a determinação da renda (cfr. o revogado artigo $4^{\circ}$, n. $^{\circ} 1$ do Decreto-Lei 149/95); e a possibilidade (imposição) de a renda ser reduzida se se verificasse qualquer circunstância que levasse à redução do preço de aquisição, mesmo que tal não se repercutisse no gozo pelo locatário (cfr. o revogado artigo $5^{\circ}$ do Decreto-Lei 149/95, que se tratava de uma concretização do princípio previsto no artigo $1040^{\circ}$ do Código Civil.). Actualmente, confirmam-no as consequências do regime de transferência do risco de que falaremos adiante no texto, com a eventualidade de o locatário financeiro ter que pagar a renda mesmo sem ter o gozo e sem a expectativa de o retomar (cfr. os artigos $12^{\circ}$ e $15^{\circ}$ do Decreto-Lei 149/95). 
${ }^{29}$ É assim que, a partir de 1995, a locação financeira pode, em função do peso relativo do valor total das rendas e do preço de aquisição a final, assumir duas feições distintas, conhecidas por full-pay-out leasing e por non-full-pay-out leasing. No full-pay-out leasing ou locação financeira total, as rendas são calculadas de modo a permitirem a amortização integral do investimento feito pelo locador financeiro e a cobertura do seu lucro, ao passo que no non-full-pay-out leasing o negócio é, em regra, previsto com uma duração inferior ao período de vida económica do bem e as rendas a pagar não permitem mais do que uma amortização parcial do investimento feito pelo locador financeiro, possibilitando-se que nem sempre seja possível aos locatários financeiros "pagar" gradualmente os bens com os rendimentos que deles se extraiam.

${ }^{30} \mathrm{~V}$. infra o capítulo sobre a natureza jurídica do contrato de locação financeira.

${ }^{31}$ Neste (último) sentido, Pedro António Sequeira de Oliveira, A resolução do contrato de locação financeira mobiliária por incumprimento do locatário Dissertação de Mestrado na área de Ciências Jurídico-Civilísticas, apresentada à Faculdade de Direito da Universidade de Coimbra, 1995, p. 193 e 194 e Guido Ferrarini, La locazione finanziaria, Giuffrè, Milão, 1977, p. 220 e 221, referido pelo primeiro na nota 643 da sua obra. Refira-se ainda a posição da jurisprudência que considera que às rendas da locação financeira não é aplicável o disposto no artigo $310^{\circ}$, alínea b) do Código Civil, não sendo o respectivo prazo de prescrição o aí fixado (cinco anos), mas o prazo ordinário de vinte anos estabelecido no artigo $309^{\circ}$ do mesmo Código. Neste sentido, o Acórdão do Supremo Tribunal de Justiça, de 4 de Outubro de 2000, CJ-STJ, ano VIII, tomo III, pp. 59 e segs., podendo ler-se a dado passo na respectiva fundamentação: "A assinalada razão de ser que lhe está subjacente não opera em relação a elas, uma vez que o decurso do tempo não faz acumular a respectiva dívida, com risco de ruína do devedor se o pagamento lhe pudesse ser exigido de um golpe passados muitos anos, como nas rendas e alugueres locatícios."

${ }^{32}$ Ao abrigo do Decreto-Lei n. ${ }^{\circ}$ 171/79, o Banco de Portugal veio, por Aviso de 7 de Junho de 1983, Diário da República, $1^{\text {a }}$ série, de 28 de Junho de 1986 - que determinava no seu n. 3 que "o valor residual (...) a que se refere o n. $^{\circ} 3$ do artigo $10^{\circ}$ do Decreto-Lei n. ${ }^{\circ} 171 / 79$ não poderá ser fixado em menos de $2 \%$ e em mais de $6 \%$ do valor do contrato" -, impor que a locação financeira de bens móveis de equipamento fosse full-pay-out, ficando excluídas, por força dos preços de aquisição simbólicos, quer a renovação do contrato, quer a devolução do bem ao locador financeiro, sendo a única atitude racionalmente possível do locatário financeiro, no final do contrato, a aquisição do mesmo. Na vigência do revogado artigo $4^{\circ}, \mathrm{n}^{\text {o }} 3$ do Decreto-Lei 149/95, o valor residual podia, relativamente aos bens móveis, variar entre $2 \%$ e $25 \%$ do valor do bem locado, sendo que, no que concerne aos bens 
imóveis, a lei não fazia qualquer referência ao limite máximo do valor residual dos mesmos, valendo o limite geral de $49,9 \%$ previsto no revogado artigo $4^{\circ}$, n. $^{\circ} 1$.

${ }^{33} \mathrm{Na}$ prática negocial, verifica-se que as rendas variam entre mensais, trimestrais ou semestrais, quanto à periodicidade, antecipadas (pagas no início do período a que se reportam) ou postecipadas (pagas no fim do período a que se reportam), quanto à data de pagamento, e constantes (assumem o mesmo valor ao longo do período contratual, sem prejuízo de serem passíveis de ajustamento em função de alterações da taxa de referência no caso de serem indexadas, o que é frequente sobretudo na locação financeira de imóveis) ou variáveis (progressivas, degressivas ou regressivas), quanto ao montante. No que respeita ao montante das rendas, este varia em função de diversos factores: montante do financiamento, valor da entrada inicial, prazo do contrato, taxa de juro negociada, valor residual acordado, etc., não valendo actualmente o limite do revogado artigo $4^{\circ}, n^{\circ} 6$ do Decreto-Lei 149/95, que determinava que o valor de cada renda não podia ser inferior ao valor dos juros correspondentes ao período a que a renda respeitasse, não podendo, então, ocorrer períodos durante o contrato sem rendas.

${ }^{34}$ Em vária jurisprudência ponderou-se que a opção de compra por parte do locatário financeiro constitui um dos elementos essenciais do contrato de locação financeira e que toda a disposição contratual restritiva de tal direito deve ser afastada por incompatível com a natureza do próprio vínculo contratual e ofensiva do seu escopo principal (cfr. infra o título sobre a jurisprudência portuguesa sobre o contrato de locação financeira).

${ }^{35}$ Neste sentido, Rui Pinto Duarte, ob. cit., p. 70 e Filipe Cassiano dos Santos, «Um exemplo...» cit., p. 8. Segundo Ricardo Munhoz, ob. cit., p. 14, se, por hipótese, o contrato for omisso no que respeita às condições relativas ao exercício e caducidade do direito de comprar, rege o disposto no artigo $411^{\circ}$ do Código Civil, podendo o locador financeiro requerer ao tribunal a fixação de prazo para o respectivo exercício, findo o qual o direito caducará.

${ }^{36}$ Segundo Ricardo Munhoz, ob. cit., p. 15, o regime actual pode conduzir a que o preço venha a assumir montantes excessivos, onerando-se, injusta e inexplicavelmente, a posição do locatário financeiro e desvirtuando-se a função de financiamento do contrato.

${ }^{37}$ Do artigo $12^{\circ}$ do Decreto-Lei n. ${ }^{\circ} 149 / 95$ resulta a irresponsabilidade do locador financeiro por danos provocados a terceiros por causa de vícios ou inadequação do bem locado, prevendo o artigo $13^{\circ}$ do Decreto-Lei n. ${ }^{\circ} 149 / 95$, como que para equilibrar, como vimos, que o locatário financeiro pode exercer contra o vendedor ou o empreiteiro todos os direitos relativos ao bem locado, não estando, por isso, no que toca aos vícios e à inadequação do bem locado, numa situação de total desprotecção. Se se trata de danos provocados a terceiros mas decorrentes da mera utilização do 
bem locado, a regra geral da responsabilidade de quem tem o domínio da coisa é confirmada pelo artigo $10^{\circ}$, n. $^{\circ} 1$, alínea j) do Decreto-Lei n. ${ }^{\circ} 149 / 95$, que, como vimos também, obriga o locatário financeiro a efectuar o seguro da coisa contra o risco dos danos por ela provocados, pressupondo que é a seu cargo que está essa responsabilidade.

${ }^{38}$ Neste sentido, cfr. o Acórdão da Relação de Lisboa, de 22 de Janeiro de 1998, cujo sumário se transcreve no ponto IV: "Tendo ficado clausulado que o contrato de locação financeira teria início da data da efectiva entrega do bem (em conformidade com o n. ${ }^{\circ} 2$ do artigo $13^{\circ}$ do DL 171/79), não tendo o bem sido entregue ao locatário, o contrato não produziu quaisquer efeitos $\left(270^{\circ} \mathrm{CCIV}\right)$, pelo que os pagamentos que a locatária haja efectuado deverão ser restituídos $\left(476^{\circ},{ }^{\circ}{ }^{\circ} 1 \mathrm{CCIV}\right)$ com juros (artigo $\left.480^{\circ}\right) . "$

39 Neste (terceiro) caso, a SLF ou o banco e o ex-locatário financeiro (ou um terceiro) podem celebrar qualquer outro negócio sobre o bem, designadamente uma locação (cfr. o artigo $7^{\circ}$ do Decreto-Lei n. ${ }^{\circ} 149 / 95$ e o artigo $1^{\circ}$, n. 2 do Decreto-Lei n. ${ }^{\circ} 72 / 95$, na redacção do Decreto-Lei n. ${ }^{\circ} 285 / 2001$. Para além disto, este artigo $1^{\circ}$ do Decreto-Lei 72/95 permite hoje (depois das alterações nele introduzidas pelo Decreto-Lei n. ${ }^{\circ}$ 285/2001) que a SLF realize operações de locação simples de bens móveis fora dos casos em que os bens lhe hajam sido restituídos no termo do contrato de locação financeira, regime que é extensível aos bancos [cfr. n. ${ }^{\circ}$ 2, alínea b) e a nova redacção do artigo $4^{\circ}$, alínea q) do RGICSF, introduzida pelo Decreto-Lei n. ${ }^{\circ}$ 285/2001]. Fica vedado às SLF's “a prestação de serviços complementares da actividade de locação operacional, nomeadamente a manutenção e a assistência técnica dos bens locados, podendo, no entanto, contratar a prestação desses serviços por terceira entidade (artigo $1^{\circ}$-A do Decreto-Lei n. ${ }^{\circ}$ 72/95, introduzido pelo DecretoLei n. ${ }^{\circ}$ 285/2001).

${ }^{40}$ A remissão para as regras gerais do incumprimento é particularmente relevante no que concerne à mora no pagamento das rendas, acarretando a necessidade de interpelação, antes da sua conversão em incumprimento definitivo (cfr. o artigo $808^{\circ}$ do Código Civil). Neste sentido, cfr. o Acórdão do STJ, de 20 de Abril de 1999, em cujo sumário se lê: "I. Constituído o devedor em mora, a lei dá ao credor a faculdade de lhe fixar um prazo razoável para sair dela mediante o pagamento de tudo o que esteja a dever, incluindo a indemnização moratória originária. Se não pagar dentro do prazo fixado, a mora considera-se retroactivamente convertida em não cumprimento, tudo se passando como se o devedor no vencimento da dívida se colocara logo nessa situação."

${ }^{41}$ A resolução importa a destruição do negócio e a cessação das obrigações dele decorrentes; mas, sendo o contrato de locação financeira um contrato de execução continuada, a resolução não obriga à restituição das prestações já efectuadas (cfr. o 
artigo $434^{\circ}$, n. $^{\circ} 2$ do Código Civil). Note-se que hoje (depois das alterações introduzidas pelo Decreto-Lei . $^{\circ}$ 285/2001), o locatário financeiro não pode precludir o efeito extintivo do contrato procedendo ao pagamento das rendas em dívida, acrescidas de $50 \%$, como permitia o revogado artigo $16^{\circ}, \mathrm{n}^{\circ} 2$ do Decreto-Lei n. ${ }^{\circ} 149 / 95$, não tendo, por outro lado, o locador financeiro que aguardar os 60 dias de mora no pagamento para poder accionar os mecanismos de resolução do contrato, como previa o n. $^{\circ} 1$ do mesmo artigo $16^{\circ}$.

${ }^{42}$ Segundo Pedro António Sequeira de Oliveira, ob. cit., p. 201, "este efeito não aparece previsto e, antes pelo contrário, o interesse do vendedor é no sentido de que o contrato de compra e venda se mantenha insensível às vicissitudes da locação financeira. A isto acresce que, por força do contrato de compra e venda, o locador adquire a propriedade do bem, não podendo este direito ser afectado por uma relação que não contende directa e imediatamente com esta questão", acrescentando o autor, em nota, que "para se acautelar desta anomalia, o locador pode inserir na compra e venda uma cláusula expressa que obrigue o vendedor a readquirir a propriedade no caso de haver a resolução da locação financeira ou, no termo do prazo, o não exercício do direito de opção." Na jurisprudência, cfr. o Acórdão da Relação do Porto, de 5 de Abril de 1994, cujo sumário em parte se transcreve: "II. Sendo a locação financeira um contrato pelo qual uma das partes se obriga, contra retribuição, a conceder à outra o gozo temporário de uma coisa, adquirida ou construída por indicação desta e que a mesma pode depois comprar, total ou parcialmente, desse contrato surgem direitos e obrigações apenas entre as partes neles contratantes. III. Daí que, com fundamento no incumprimento do contrato de locação financeira, não possa o locatário pretender a anulação do contrato de compra e venda pela locadora eventualmente celebrado com terceiro, com vista ao cumprimento daquele contrato de locação."

${ }^{43}$ Como bem alerta Filipe Cassiano dos Santos, «O contrato de leasing»... cit., p. 36, a questão complica-se "se se verificar que foi o locatário a negociar ou a dar causa à situação geradora de invalidade ou resolução. Nestes casos, poder-se-á entender que não há incumprimento por parte da SLF ou que há abuso na invocação da nulidade ou na resolução por parte do locatário e, mesmo que o contrato se venha a extinguir, poderão concorrer os pressupostos para que a SLF obtenha uma indemnização por parte do locatário, por ter contribuído para o incumprimento ou mesmo por execução defeituosa do mandato, se o houver. Nestes casos, haverá responsabilidade do locatário pela não concretização do negócio." Aliás, com frequência, incluem-se nos contratos cláusulas segundo as quais o incumprimento da obrigação de entrega não responsabiliza o locador financeiro, afastando tal obrigação da esfera do locador financeiro. Sobre isto, v. infra o capítulo sobre a jurisprudência portuguesa sobre o contrato de locação financeira. 
${ }^{44}$ Note-se que o artigo $936^{\circ}$, n. $^{\circ} 2$ do Código Civil - cuja ratio é evitar que a aplicação das normas sobre vendas a prestações constantes dos artigos $934^{\circ}$ e $935^{\circ}$ do mesmo Código seja iludida pela adopção de figurinos que, embora funcionalmente homólogos, sejam estruturalmente diversos - tem em vista também os contratos de ALD que pretendam obter um resultado equivalente ao da venda a prestações.

45 V. Giuseppe Mirabelli, Il leasing e il diritto italiano, BBTC, 1974, ano XXXVII, I e Giorgio De Nova, Il contrato di leasing com 170 sentenze ed altri materiali, $2^{\mathrm{a}}$ edição, Giuffrè, 1985, citados por Pedro António Sequeira de Oliveira, ob. cit., p. 162, nota 529. Segundo Emanuele Lucchini, «La risoluzione del contratto di leasing finanziario», Rivista Trimestrale di Diritto e Procedura Civile, ano XLV, p. 492, são estes os principais argumentos avançados: “a) in entrambi i contratti i canoni assumono valori di corrispettivo sia del godimento del bene, sia del futuro trasferimento della proprietà; b) in entrambi i contrati è presente lo scopo di finanziamento (scopo, è opportuno sottolinearlo, e non causa di finanziamento); c) in entrambi i negozi la conservazione della proprietà in capo al concedente (o venditore) ha funzione di garanzia; d) il riscio del perimento del bene si trasferisce immediatamente in capo all'utilizzatore o all'acquirente (ex lege nella vendita com riserva della proprietà, in virtù di una clausola contrattuale nel leasing.)" Não se conhecem em Portugal posições que vão no sentido do texto.

${ }^{46}$ V. Carlos Alberto Mota Pinto, «Um nova modalidade jurídica de financiamento industrial: o leasing», Ciência e Técnica Fiscal, n. ${ }^{\circ}$ 99, Março de 1967, pp. 231 e segs., Teresa Anselmo Vaz, Alguns aspectos do contrato de compra e venda a prestações e contratos análogos, Coimbra, Almedina, 1995, pp. 87 e segs. e Diogo Leite de Campos, A locação financeira, Lex, Lisboa, 1994, p. 132 e 133, citados por Pedro António Sequeira de Oliveira, ob. cit., p. 165, nota 542. Este autor, ob. cit., pp. 34 e segs., distingue o hire purchase (figura próxima da locação com opção de compra) e a locação-venda da locação financeira, dizendo, quanto ao hire purchase, que a diferença se reconduz à filosofia subjacente aos dois contratos: "No contrato de finance leasing, o proprietário concebe o bem como capital, obtendo o rendimento do mesmo; no contrato de hire purchase, o owner configura-o como património ou stock, retirando um lucro da sua venda, ainda que a posteriori. Isto mesmo justifica que este bem seja inscrito no património do bailee. Se atendermos, ainda, à posição da contraparte, verificamos que o contrato de hire purchase está vocacionado para o consumo, sendo objectivo do bailee a aquisição do próprio bem enquanto tal." Quanto à locação-venda, em que se verifica a automaticidade do efeito translativo próprio da compra e venda a prestações com reserva da propriedade, o autor considera que "no contrato de leasing, tal como no contrato de hire purchase, a aquisição da propriedade é eventual, ou seja, depende do exercício da opção de aquisição por aquele sujeito que utiliza a coisa. Já no contrato de locação-venda a aquisição da propriedade opera-se 
automaticamente com o pagamento da última prestação. Além de que na locaçãovenda as prestações (rendas-prestações) não incluem o risco financeiro característico da locação financeira, porquanto, ao contrário deste, a transferência da propriedade é um efeito forçoso e imediato do contrato. O locador-vendedor não suporta nenhum risco financeiro."

${ }^{47}$ Neste sentido, Filipe Cassiano dos Santos, «Um exemplo...» cit., p. 11. Segundo o autor, a cedência do gozo que se realiza por força do contrato de locação financeira é "uma antecâmara do potencial gozo próprio do proprietário do bem, justificada por o locatário financeiro ter assumido a obrigação de pagar o investimento do locador."

${ }^{48}$ V., por todos, Maria Veiga de Faria, «Leasing e locação financeira: aspectos contabilísticos, financeiros e fiscais», Ciência e Técnica Fiscal, 1984, n. ${ }^{\circ}$ 307-309, pp. 481 e segs., citada por Pedro António Sequeira de Oliveira, ob. cit., p. 190, nota 626.

${ }^{49}$ V. João de Matos Antunes Varela, Das obrigações em geral, vol. I, Almedina, Coimbra, 1994, p. 283: "Verdadeiro contrato misto terá constituído, entre nós e noutros países europeus, durante algum tempo, o chamado contrato de leasing que, numa das suas modalidades mais frequentes, envolvia uma associação curiosa de prestações do contrato de locação com prestações da compra e venda ou do compromisso de venda. A partir, porém, de 1979 (Dec.-Lei n. ${ }^{\circ}$ 135/79, de 18.5; Dec.-Lei n. ${ }^{\circ}$ 171/79, de 6.6; Dec.-Lei n. ${ }^{\circ} 11 / 84$, de 7.1 e Dec.-Lei n. ${ }^{\circ} 103 / 86$, de 19.5), o leasing converteu-se entre nós num contrato nominado, sob o nomen iuris de contrato de locação financeira." e Pedro António Sequeira de Oliveira, ob. cit., p. 195: "Daqui resulta a reunião de várias técnicas de contratos típicos, mais precisamente da locação e da compra. No entender da doutrina contratos mistos são aqueles que reúnem elementos característicos de contratos típicos, referindo-se a eles o artigo $405^{\circ}, n^{\circ} 2$. Actualmente, o contrato de locação financeira goza de um nomen iuris e de um regime jurídico substantivo, constante do DL 149/95, pelo que se insere na categoria dos contratos nominados ou típicos. Parece, por conseguinte, que nos encontramos no seio dos contratos nominados mistos." Na verdade, como bem sublinha Rui Pinto Duarte, Tipicidade e atipicidade dos contratos, Almedina, Coimbra, 2000, p.47, a noção de contrato misto "é aplicada não só a contratos concretos mas também a espécies legais (que, deste modo, são analisadas noutras espécies legais mais simples, elementares), embora normalmente apareça referida àqueles e certos autores expressamente a reservem para os mesmos." Na jurisprudência, cfr. o Acórdão da Relação de Lisboa, de 20 de Setembro de 1994, CJ, ano XIX, tomo IV, p. 89: "Encurtando caminhos e argumentos temos, com o Prof. Leite de Campos, loc. cit., p. 73, 'numa análise mais estrutural, que o contrato de locação financeira contém elementos dos tipos compra e venda e locação sendo, pois, um contrato nominado misto."” e o Acórdão do mesmo Tribunal, de 18 de Fevereiro de 1999, CJ, ano XXIV, 
tomo I, p. 116: "A doutrina conhecida sobre a locação financeira, também designada por leasing, tem entendido que constitui um misto dos contratos de locação e de compra e venda: cfr., neste sentido, inter alia, Leite de Campos, A Locação Financeira, Lisboa, 1994, p. 25; Pedro Romano Martinez, Contratos em Especial, Lisboa, 1996, p. 309; João Calvão da Silva, «Locação financeira e garantia bancária», Estudos de Direito Comercial (Pareceres), Almedina, 1996, nota 21 in fine da p. 29, para quem '(...) o leasing é um contrato misto erguido pela lei portuguesa a contrato típico ou nominado."”

${ }^{50}$ Segundo o autor, ob. e p. cit., "o núcleo do contrato de locação financeira corresponde, no direito português, à essência de uma locação, pese embora o facto de algumas, não poucas, das normas especiais sobre a locação financeira contrariarem o regime geral da locação. A esta parte do contrato de locação financeira acresce uma outra consistente num contrato-promessa unilateral sobre a coisa locada. E como entre estas duas componentes do contrato não existe mais do que um nexo de dependência funcional, a expender-se uma qualificação doutrinária, ela terá de ser a de que a locação financeira é uma união ou coligação de contratos (e não um contrato misto)."

${ }^{51}$ Para mais desenvolvimentos sobre o tema da união de contratos e das fronteiras relativamente ao contrato misto, v. João de Matos Antunes Varela, ob. cit., pp. 283 e segs. e Rui Pinto Duarte, Tipicidade e atipicidade... cit., pp. 50 e segs. Segundo este autor, últ. ob. cit., p. 55, "os contratos unidos vivem 'a sua vida própria e independente', salvo no que resulte do regime traçado para a figura na qual a união se resolva."

${ }^{52}$ Num sentido (muito) próximo ao do texto, v. Filipe Cassiano dos Santos, «Um exemplo...» cit., p. 5 e 6: " (...) são precisamente os novos aspectos sublinhados - o específico fim a que se subordina e a mutação de regime - que caracterizam e autonomizam o leasing enquanto nova modalidade contratual, designadamente face à locação. Significa isto que nem o negócio no seu todo, nem mesmo a cessão do gozo que é uma das convenções que dele fazem parte, têm natureza locatícia." Dignas de citação são também as palavras de Vincenzo Zeno-Zencovich, «Il controllo giudiziale sull'equivalenza delle prestazioni nei contratti di leasing», Rivista del Diritto Commerciale e del Diritto Generale delle Obbligazioni, 1985, parte seconda, p. 310 e 311: "Nel contratto di leasing paiono individuabili due funzioni reconducibili a interessi precisi: quella di scambio e quella di finanziamento. La prima risulta dal trasferimento all'utilizzatore, da parte del concedente, di un bene del quale el primo può iniziare subito il godimento; la seconda dal ruolo di intermediazione finanziaria che svolge la società di leasing fra il produttore del bene e l'utilizzatore. N'é l'una, n'é l'altra paiono - come si fa in talune interpretazioni - eliminabili, ed anzi proprio molti equivoci e contrasti appaiono determinanti dal tentativo di scindere i due aspecti." 
${ }^{53}$ Problema conexo, mas independente, do no ponto anterior referido.

${ }^{54}$ V. supra o capítulo sobre a natureza jurídica do contrato de locação financeira.

${ }^{55}$ Cfr. o (já referido) Acórdão do STJ, de 7 de Março de 1991, cujo sumário se transcreve: "I. É essencial ao contrato de locação financeira o gozo temporário e oneroso da coisa locada pelo locatário, que pode comprá-la, mas não pode ser obrigado, por convenção a efectuar a compra. II. A cláusula de um contrato de locação financeira que, finda a locação, obrigue o locatário a comprar a coisa locada é proibida e, consequentemente, nula, de harmonia com as disposições dos artigos $9^{\circ}$, $12^{\circ}, 19^{\circ}$ e $22^{\circ}$ do Decreto-Lei n. ${ }^{\circ} 446 / 85$, de 25 de Outubro. III. Semelhante cláusula concede à parte contratual economicamente mais forte a vantagem - ofensiva do equilíbrio contratual - de receber todas as quantias devidas pela locação e, além disso, obrigar a outra parte a ficar com a coisa locada - contra a natureza do contrato e contra um seu elemento importante, o direito de não a adquirir. IV. Pode o locatário optar pela resolução do contrato, restituindo a coisa locada, por força do artigo $9^{\circ}$ do aludido Decreto-Lei.", o Acórdão da Relação de Lisboa, de 27 de Fevereiro de 1992, $C J$, ano XVIII, 1992, tomo I (pese embora a infelicidade da redacção da cláusula contratual em causa, que enquadrava o direito do locador financeiro no âmbito da resolução do contrato) cujo sumário também se transcreve em parte: "II. É nula a cláusula de um contrato de locação financeira que estabelece para o locador, no caso de resolução do contrato, o direito à indemnização do interesse contratual positivo, visto que tal cláusula viola o disposto no artigo $801^{\circ}, n^{\circ} 1$ do Código Civil sobre a indemnização, disposição esta que não pode ser afastada por vontade das partes.", o Acórdão do STJ, de 5 de Julho de 1994, em que se conclui que "é nula a cláusula geral de contrato de locação financeira que estabelece, para caso de incumprimento do contrato por falta de pagamento de rendas pelo locatário, o pagamento das rendas vencidas e vincendas e do valor residual dos equipamentos locados e respectivos juros moratórios, face ao disposto nos artigos $12^{\circ}$ e $19^{\circ}$, alínea c) do Decreto-Lei n. ${ }^{\circ} 446 / 85$, de 25 de Outubro.", o Acórdão do mesmo Supremo Tribunal, de 5 de Setembro de 1994, CJ-STJ, ano II, tomo II, p. 173, em cuja fundamentação se lê a dado passo: "É da essência do contrato de locação financeira não forçar o locatário a adquirir a coisa locada; ele só a adquire se optar por isso (...) já que a venda não pode ser imposta ao locatário." e, por último, o Acórdão da Relação de Lisboa, de 4 de Março de 1997, podendo ler-se no ponto III do respectivo sumário: "É da essência do contrato de locação financeira não forçar o locatário a adquirir a coisa locada; só a adquire se o optar."

${ }^{56}$ No sentido do texto, v. Rui Pinto Duarte, ob. cit., p. 186: "Sendo o 'leasing' financeiro uma forma de financiamento, não há que recusar que o seu regime, em muitos aspectos, se aproxime do do mútuo. Ora, como é bem sabido, no mútuo reembolsável a prestações, a falta de pagamento de uma prestação pelo mutuário 
determina a exigibilidade antecipada das quantias vincendas, por força do regime geral das obrigações (artigo 781 do Código Civil)."

${ }^{57}$ Considerações como as referidas no texto devem ter estado na origem da recente revogação, pelo Decreto-Lei n. $^{\circ}$ 285/2001, do artigo $20^{\circ}$ do Decreto-Lei $149 / 95$.

${ }^{58}$ Nos termos do artigo $13^{\circ}$, n..$^{\circ} 2$ da referida Convenção do Unidroit sobre Locação Financeira Internacional: "Se o incumprimento pelo locatário for substancial, o locador, sem prejuízo do disposto no parágrafo 5 deste artigo, pode exigir o pagamento antecipado do valor das rendas futuras, se tal estiver previsto no contrato de locação financeira, ou resolver o contrato de locação financeira e consequentemente: a) reaver o equipamento; e b) exigir uma indemnização que o coloque na situação em que se encontraria se o locatário tivesse cumprido pontualmente o contrato de locação financeira."

${ }^{59}$ Cfr., neste sentido, o (já referido) Acórdão da Relação de Lisboa, de 20 de Setembro de 1994, cujo sumário em parte se transcreve: "II. É válida a cláusula que confira ao locador o direito de, em caso de incumprimento, exigir o valor das rendas futuras."

${ }^{60}$ No sentido do texto, cfr. o Acórdão da Relação de Lisboa, de 18 de Maio de 1995, em cujo sumário se lê: "III. Ao incumprimento por parte da locatária a locadora poderá optar por uma de duas soluções: a) resolver o contrato; ou b) exigir de imediato o valor total das rendas não pagas, vencidas e vincendas, mais o valor residual; em alternativa, não cumulativamente."

${ }^{61}$ Note-se que, não obstante o direito de resolução do contrato de compra e venda (ou de empreitada) competir, em geral, ao locador financeiro, é frequente os contratos de locação financeira que incluem a cláusula referida no texto atribuírem o direito de resolução daquele contrato ao locatário financeiro. Se o contrato não atribuir esse direito ao locatário financeiro, este poderá invalidar ou resolver o contrato de compra e venda (ou de empreitada) com base no disposto no artigo $13^{\circ}$ do Decreto-Lei n. ${ }^{\circ}$ 149/95. Neste sentido, Filipe Cassiano dos Santos, «O contrato de leasing»... cit., p. 36. Contra a possibilidade de, na falta de disposição contratual, o locatário financeiro invalidar ou resolver o contrato de compra e venda (ou de empreitada), devendo antes o locador financeiro, por força da boa fé contratual, resolver a compra e venda (ou a empreitada), depois de devidamente informado pelo locatário do incumprimento do fornecedor, v. Pedro António Sequeira de Oliveira, ob. cit., p. 200, nota 667.

${ }^{62}$ V. Guido Ferrarini, La locazione finanziaria, Giuffrè, Milão, 1977, pp. 76 e segs., citado por Pedro António Sequeira de Oliveira, ob. cit., p. 214, nota 711.

${ }^{63} \mathrm{Na}$ prática negocial, é, com efeito, muito frequente a outorga ao locatário financeiro dos poderes necessários para a representação do locador financeiro na recepção do bem locado. 
${ }^{64}$ No sentido do texto, v. João Calvão da Silva, «Locação financeira e garantia bancária», Estudos de Direito Comercial (Pareceres), Almedina, Coimbra, 1999, pp. 22 e segs..

${ }^{65}$ No sentido do texto, v. Rui Pinto Duarte, ob. cit., p. 215 e 216: "A regra legal segundo a qual cabe ao locador financeiro conceder o gozo do bem locado não pode ser interpretada como pondo a cargo do locador o risco de o fornecedor não cumprir." Na jurisprudência, cfr. o Acórdão da Relação do Porto, de 12 de Junho de 1997, em cujo sumário se lê: "I. A obrigação que o locador tem de conceder o gozo da coisa traduz-se na entrega da mesma ao locatário, entrega esta que pode ser feita através do vendedor ou fornecedor que, nesse caso, funciona como auxiliar do locador. II. A compra do bem, embora financiada pelo locador, é assunto que diz respeito ao locatário e ao fornecedor, não devendo o primeiro suportar quaisquer prejuízos que derivem do não cumprimento."

${ }^{66}$ Segundo António Pinto Monteiro, «Cláusulas limitativas e de exclusão de responsabilidade civil», Boletim da Faculdade de Direito da Universidade de Coimbra, supl., vol. XXVIII, Coimbra, p. 103, este tipo de cláusulas "afastam do contrato obrigações que, sem essa manifestação de vontade, dele fariam parte, por força de preceito legal, ou por constituírem deveres acessórios (adjacentes) da prestação principal ou, em geral, do fim contratual." Mas, alerta o autor, "não poderão excluir-se do contrato obrigações que constituam elementos essenciais do negócio típico ou nominado escolhido pelas partes, sob pena de total descaracterização do mesmo", nem obrigações que, “embora não afectem a causa negotii, obstem, contudo, de uma forma radical, à obtenção do resultado pretendido, por se tratar de obrigações essenciais ao fim contratual." (Ob. cit., p. 112 e 113). No sentido do texto, v. Pedro António Sequeira de Oliveira, ob. cit., p. 213, nota 709. Segundo o autor, o afastamento da obrigação de entrega do bem locado não compromete o fim contratual "justamente porque, segundo a intenção das partes, tais obrigações não cabem na esfera contratual da entidade locadora, que apenas arca com a responsabilidade de carácter financeiro."

${ }^{67}$ Rui Pinto Duarte, ob. cit., p. 211, nota 7, constata que o facto de todos ou quase todos os contratos de locação financeira anteriores ao Decreto-Lei n. ${ }^{\circ}$ 168/99, de 24 de Maio, preverem uma tal cláusula é consequência da imposição feita pelo artigo $4^{\circ}$, n. ${ }^{\circ} 2$ do Decreto-Lei n. ${ }^{\circ} 171 / 79$ de que os modelos de contrato fossem submetidos à aprovação prévia do Banco de Portugal. Alerte-se, a este propósito, para a necessidade de, face às alterações introduzidas no Decreto-Lei n. ${ }^{\circ}$ 149/95 pelo Decreto-Lei n. ${ }^{\circ} 285 / 2001$, serem revistos os modelos de contrato utilizados pelos locadores financeiros, designadamente no que respeita a prazos, rendas e valor residual, na medida em que os artigos $4^{\circ}$ (rendas e valor residual), $5^{\circ}$ (redução das rendas), $16^{\circ}$ 
(mora no pagamento das rendas) e $20^{\circ}$ (antecipação das rendas) daquele Decreto-Lei foram revogados por este.

${ }^{68}$ V. João de Matos Antunes Varela, ob. cit., vol. II, pp. 105 e segs., Mário Almeida Costa, Direito das obrigações, 6 ed., Almedina, Coimbra, 1995, p. 917 e Fernando Pessoa Jorge, Lições de direito das obrigações, Associação Académica da Faculdade de Direito de Lisboa, Lisboa, 1966-1967, p. 634, citados por Pedro António Sequeira de Oliveira, ob. cit., p. 238, nota 809. Na jurisprudência, cfr. o Acórdão da Relação do Porto, de 3 de Junho de 1997, cujo sumário se transcreve no que ora releva: "I. No artigo $801^{\circ}$, n. ${ }^{\circ} 2$ do Código Civil cumulam-se o direito à resolução e o direito à indemnização do prejuízo que o credor não teria sofrido se o contrato não tivesse sido celebrado (interesse contratual negativo).", o Acórdão da Relação do Porto, de 11 de Novembro de 1997, transcrevendo-se o ponto I do respectivo sumário: "I. Resolvida pela locadora o contrato de locação financeira com base na falta de pagamento das rendas vencidas, pode aquela exigir dos locatários a restituição dos equipamentos locados, as rendas vencidas à data da resolução e não pagas, com juros de mora, bem como ainda uma indemnização pelo interesse contratual negativo resultante do incumprimento do contrato." e o Acórdão da Relação do Porto, de 23 de Maio de 2000, transcrevendo-se, também, parte do respectivo sumário: "I. Não tendo o locatário cumprido a obrigação do pagamento das rendas convencionadas no contrato de locação financeira, a locadora que opta pela resolução do contrato não pode pretender a indemnização do interesse contratual positivo correspondente aos benefícios que teria auferido com o cumprimento do contrato. II. É que a resolução do contrato é equiparada, quanto aos seus efeitos, à nulidade ou anulabilidade do negócio jurídico, e sendo o negócio destruído, tal não pode ser equiparado ao seu cumprimento."

${ }^{69}$ Diga-se apenas que não nos choca que as partes convencionem para o caso de incumprimento pelo locatário financeiro uma indemnização que coloque o locador financeiro na situação em que se encontraria se aquele tivesse cumprido pontualmente o contrato (v. o que a seguir se diz no texto). Neste sentido, de necessidade de tutela do interesse do cumprimento e, por isso, a favor da indemnização do interesse contratual positivo em simultâneo com o exercício do direito de resolução, v. Adriano Vaz Serra, «Mora do devedor», BMJ, n. ${ }^{\circ}$ 47, 1955, pp. 30 e segs., João Baptista Machado Porto, Direito das obrigações (aditamento), 1982, pp. 3 e segs. e Jorge Ribeiro de Faria, «A natureza do direito de indemnização cumulável com o direito de resolução dos arts. $801^{\circ}$ e $802^{\circ}$ do Código Civil», Direito e Justiça, 1994, vol. VIII, tomo I, pp. 81 e segs., citados por Pedro António Sequeira de Oliveira, ob. cit., p. 238, nota 812. Na jurisprudência, cfr. o Acórdão da Relação de Lisboa, de 12 de Outubro de 1995, em cujo sumário se lê: "I. Aceitando-se que a indemnização por resolução do contrato a que se refere o n..$^{\circ} 2$ do artigo $801^{\circ}$ do $\mathrm{CC}$ se destina à reparação do dano 
contratual negativo, tal norma não é imperativa, pelo que nada impede se convencione, para tal situação, a reparação do dano contratual positivo. II. No contrato de locação financeira, a actividade do locador é, essencialmente, financeira, não estando vocacionado para a retoma dos equipamentos locados ou nova locação. III. Em tal contrato, o incumprimento do locatário conduz ao não recebimento de remuneração prevista no contrato e à restituição de um equipamento que sofreu no período inicial da sua utilização a maior desvalorização a que estava sujeito, subsistindo, por isso, ainda um prejuízo do locador." Neste sentido, também o (já referido) artigo $13^{\circ}$, n. $^{\circ}$ 2, in fine da Convenção do Unidroit sobre Locação Financeira Internacional.

70 Acórdão da Relação do Porto, de 23 de Novembro de 1993, CJ, ano XVIII, tomo V, p. 228.

${ }^{71}$ Cfr. o Acórdão da Relação de Lisboa, de 2 de Novembro de 1995, cujo sumário em parte se transcreve: "II. É válida, porém, a cláusula de tal contrato que estipule o pagamento ao locador, a título de perdas e danos por este sofridos, de uma importância igual a $20 \%$ da soma das rendas vincendas com o valor residual, por se tratar de uma cláusula penal admitida nos termos gerais, a par da resolução do contrato, pelo regime legal do contrato de locação financeira. III. Na indemnização coberta pela cláusula penal não há que atender apenas ao prejuízo do não recebimento das rendas convencionadas, que não se chegaram a vencer, pois a este valor acresce o da desvalorização do próprio equipamento, desvalorização que também afecta o seu valor residual e que é equitativo fixar em 50\%.", o Acórdão da mesma Relação, de 30 de Setembro de 1997, podendo ler-se no correspondente sumário: "Em contrato de locação financeira é válida, por não desproporcionada aos danos a ressarcir, a cláusula segundo a qual, em caso de resolução do contrato pelo locador com fundamento em incumprimento definitivo do locatário, além do direito à restituição imediata do locado, e a conservar as rendas vencidas e pagas, e a receber as rendas vencidas e não pagas, o locador tem ainda o direito a um montante indemnizatório igual a $20 \%$ da soma das rendas vincendas com o valor residual, e salvo o direito de exigir a reparação integral dos seus danos.", o Acórdão da Relação do Porto, de 11 de Novembro de 1997, cujo sumário também se transcreve em parte: "III. Estando em causa no contrato equipamentos normalmente desactualizáveis ou de rápido desgaste pelo uso, não pode considerar-se excessiva a cláusula penal que obriga o locatário a pagar, em caso de incumprimento, $20 \%$ da soma das rendas vincendas com o valor residual." e o Acórdão do mesmo tribunal, de 2 de Abril de 1998, em cujo sumário se conclui: "No contrato de locação financeira mobiliária, não se deve considerar desproporcionada, face a desvalorização que sempre sofre o bem pela sua utilização e ainda pela resultante da evolução tecnológica, a cláusula que fixa, no caso de incumprimento pelo locatário, para além do direito à restituição do bem e do 
pagamento das rendas vencidas, a indemnização igual a $20 \%$ da soma das rendas vincendas com o seu valor residual."

${ }^{72}$ Cfr., por todos, o Acórdão do STJ, de 15 de Dezembro de 1998, cujo sumário se transcreve na totalidade: "I. O locador não tem que provar os danos concretos a que corresponde a previsão da cláusula penal, a qual tem justamente por escopo a fixação prévia, por acordo das partes, do montante indemnizatório. II. Sobre o locatário impende o ónus de alegar e provar factos dos quais se possa concluir pela desproporção entre o valor resultante da cláusula penal e os danos a ressarcir. II. Coisa diversa do ónus da prova do dano é a que consiste na avaliação do eventual excesso da cláusula. IV. Embora não tenham sido alegados factos susceptíveis de levar a concluir pelo carácter desproporcionado da cláusula, impõe-se, a partir da factualidade provada, ponderar e decidir acerca da proporcionalidade ou do manifesto excesso da cláusula. V. Representaria manifesta violação do espírito da lei abstrair do montante concreto a que conduz, em cada caso, a aplicação da cláusula, cotejando tal 'quantum' com as circunstâncias de facto do caso concreto, a fim de apurar se a cláusula é ou não manifestamente desproporcionada aos danos a ressarcir. VI. O juiz só pode concluir pelo carácter 'manifestamente excessivo' da cláusula, após ponderar uma série de outros factores, à luz do caso concreto, que um julgamento por equidade requer. VII. Para se afirmar, à luz do disposto no artigo $19^{\circ}$, alínea c), do DL 446/85, de 25 de Outubro, a desproporcionalidade da cláusula, é preciso proceder a uma comparação entre o montante da indemnização que resulta dessa cláusula e a ordem de grandeza dos prejuízos que o locador sofrerá com o incumprimento. VIII. Em certas situações de manifesta injustiça, ponderados os factores conhecidos, a equidade pode conduzir a que o tribunal reduza a cláusula a limites razoáveis, à luz do artigo $812^{\circ}$ do C. Civil, em cuja linha de pensamento se inserem normas como a do artigo $334^{\circ}$ do mesmo Código."

${ }^{73}$ Para Vincenzo Zeno-Zencovich, loc. cit., p. 315 e 316, "se da un lato non è dubio il ruolo di finanziatore che il concedente svolge in due sensi, e cioè sia nei confronti del fornitore cui versa immediatamente ed in una unica soluzione il prezzo, sia nei confronti dell'utilizzatore cui consente l'immediato godimento del bene (e tale duplicità di funzione è per così dire l'uovo di Colombo del leasing, congiungendo l'intermediazione finanziaria al rinnovamento tecnologico dell'impresa), d'altro canto non è possibile ignorare che il principio sinallagmatico vige per tutti i contratti a prestazioni corrispettive, sia che la causa venga individuata nel trasferimento di beni, sai che essa si qualifichi per la funzione di finanziamento." Um caso de manifesta injustiça e abuso foi, parece-nos, o decidido pelo Acórdão da Relação do Porto, de 3 de Julho de 1998, em cujo sumário se lê: "Porque o contrato de locação financeira para compra de veículos automóveis exige um elevado investimento financeiro e proporciona, no caso de incumprimento pelo locatário, a colocação no mercado de 
veículos usados que não disporão da mesma aceitação dos consumidores, não é desproporcionada a cláusula penal que obriga ao pagamento do dobro das rendas que seriam devidas se o contrato permanecesse válido."

\section{BIBLIOGRAFIA}

ANTUNES VARELA, João de Matos (1994), Das obrigações em geral, vol. I, Almedina, Coimbra.

CALVÃO DA SILVA, João (1999), «Locação financeira e garantia bancária», Estudos de Direito Comercial (Pareceres), Almedina, Coimbra.

CARRETA, Alessandro/ LAUREnTIS, Giacomo de (1998), Manuale del leasing, EGEA, Milano.

CASSIANO DOS SANTOS (1994), «O contrato de leasing», Apontamentos de Direito Comercial II, Faculdade de Direito da Universidade de Coimbra.

CASSIANO DOS SANTOS (sem data $-\mathrm{s} / \mathrm{d}$ ), «Um exemplo das novas tendências do direito comercial: o contrato de locação financeira entre a origem civilística e a comercialidade», Apontamentos de Direito Comercial II, Faculdade de Direito da Universidade de Coimbra.

CORREIA DOS SANTOS (1986), Contrato de locação financeira - Instituições parabancárias, Coimbra Editora, Ld. ${ }^{\text {, }}$ Coimbra.

DUARTE, Rui Pinto (1992), «Alguns aspectos jurídicos dos contratos não bancários de aquisição e uso de bens», Revista da Banca, n. ${ }^{\circ}$ 22, Abril-Junho, pp. 49 e segs..

DUARTE, Rui Pinto (2000), Tipicidade e atipicidade dos contratos, Almedina, Coimbra.

DUARTE, Rui Pinto (2001), Escritos sobre leasing e factoring, Principia, S. João do Estoril, Cascais.

INVREA, Raffaele/ LONGO, Mario (1999), Leasing - legislazione, casi pratici, dottrina, giurisprudenza, Giuffrè Editore, Milano.

LEITE DE CAMPOS, Diogo Paredes (1982), «Nota sobre a admissibilidade da locação financeira restitutiva ('lease-back') no direito português», Revista da Ordem dos Advogados, ano 42, III, Set.-Dez., pp. 775 e segs..

LEITE DE CAMPOS, Diogo Paredes (1983), «A locação financeira na óptica do utente, Revista da Ordem dos Advogados, ano 43, Lisboa, pp. 319 e segs..

LEITE DE CAMPOS, Diogo Paredes (1987), «Ensaio de análise tipológica do contrato de locação financeira, Boletim da Faculdade de Direito, vol. 63, pp. 1 e segs.. 
LUCCHINI, Emanuele (1991), «La risoluzione del contratto di leasing finanziario», Rivista Trimestrale di Diritto e Procedura Civile, pp. 491 e segs..

MARTINEZ, Pedro Romano (1995), Contratos em especial, Universidade Católica Editora, Lisboa.

MOITINHO DE ALMEIDA, José Carlos (1973), «A locação financeira (leasing)», Boletim do Ministério da Justiça, Lisboa, n. ${ }^{o}$ 231, Dez., pp. 5 e segs..

MUNHOZ, Ricardo (1997), "Contrato de leasing (locação financeira)», Revista Portuguesa de Direito de Consumo, n. ${ }^{\circ}$ 12, Dez., Coimbra.

PESTANA DE VASCONCELOS, Duarte Vieira (1985), «A locação financeira», Revista da Ordem dos Advogados, ano 45, I, Abril, pp. 243 e segs..

PINTO MONTEIRO, António Joaquim de Matos (1985), «Cláusulas limitativas e de exclusão de responsabilidade civil», Boletim da Faculdade de Direito da Universidade de Coimbra, supl., vol. XXVIII, Coimbra.

PINTO MONTEIRO, António Joaquim de Matos (1990), Cláusula penal e indemnização, Almedina, Coimbra.

PIZARRO, Sebastião Nóbrega/ CALIXTO, Margarida Mendes (1995), Contratos financeiros - leasing, agência, franchising, factoring, permuta, mútuo, Almedina, Coimbra.

RUOZI, Roberto e outros (1990), La tutela del consumatore di servizi finanziari, Egea, Milano.

SEGURADO LLORENTE, Juan Luis (1992), El leasing, Editorial De Vecchi, Barcelona.

SEQUEIRA DE OLIVEIRA, Pedro António (1995), A resolução do contrato de locação financeira mobiliária por incumprimento do locatário - Dissertação de Mestrado na área de Ciências Jurídico-Civilísticas apresentada à Faculdade de Direito da Universidade de Coimbra.

VALENTE, J. Rosado (1994), Locação financeira (leasing) - Aluguer de longa duração (ALD), Minerva, Coimbra.

ZENO-ZENCOVICH, Vincenzo (1985), «Il controllo giudiziale sull'equivalenza delle prestazioni nei contratti di leasing», Rivista del Diritto Commerciale e del Diritto Generale delle Obbligazioni, parte seconda, pp. 309 e segs. 